\title{
LEALTAD CONSTITUCIONAL Y DEMOCRACIA
}

ROSARIO TUR AUSINA 


\section{INDICE}

1. PREMISA. 2. ORÍGENES Y EVOLUCIÓN DEL PRINCIPIO DE LEALTAD CONSTITUCIONAL. 3. FUNDAMENTO Y JUSTIFICACIÓN DE LA LEALTAD CONSTITUCIONAL. 4. LEALTAD CONSTITUCIONAL Y ORDENAMIENTO JURÍDICO. 5. LEALTAD CONSTITUCIONAL Y EJERCICIO DEL PODER. 6. LEALTAD CONSTITUCIONAL EN UN SISTEMA MULTINIVEL. 7. CONCLUSIONES. 


\title{
LEALTAD CONSTITUCIONAL Y DEMOCRACIA
}

\author{
ROSARIO TUR AUSINA ${ }^{1}$ \\ Catedrática de Derecho constitucional \\ Universidad Miguel Hernández de Elche \\ "Las peores disputas no surgen hasta que \\ ambas partes tienen razón y están equivocadas \\ por igual»
}

Winston Churchill (1874-1965)

\section{A MODO DE PREMISA}

El presente trabajo constituye un análisis desde la teoría y la práctica constitucional, sobre la eficacia y alcance de la Constitución del 78 desde un balance de cuarenta años de democracia. Y para ello se parte de la configuración dogmática del principio de lealtad constitucional, aunque para constatar de antemano que el mismo no tiene un acomodo específico en el texto de nuestra Carta Magna ni puede decirse que haya recibido excesiva atención doctrinal ni jurisprudencial. Ello no significa, sin embargo, que no puedan encontrarse ciertas reflexiones sobre la lealtad desde un enfoque jurídico, en específicos sectores del ordenamiento, y en el derecho comparado mismo: lealtad institucional, lealtad federal, etc. Pero siendo de algún modo útiles estos desarrollos para el análisis del principio de lealtad constitucional, resultan no obstante insuficientes.

Salvo durante el bienio 1977-1979, la lealtad constitucional parece haber brillado en nuestro país por su ausencia, posiblemente debido a la falta de una auténtica cultura del diálogo y la cooperación. Durante este periodo se formalizaron, expresa o tácitamente, acuerdos que condujeron a la celebración de las primeras elecciones democráticas en 1977 (incluida la legalización del PCE y el acuerdo sobre las normas

${ }^{1}$ Catedrática de Derecho Constitucional. Departamento de Ciencia Jurídica. Universidad Miguel Hernández de Elche. Edif. Torrevaillo. Avda. de la Universidad, s/n. 03202 ELCHE. Email: charo.tur@ umh.es 
electorales a aplicar); la aplicación de los Acuerdos de la Moncloa y la elaboración de la propia Constitución. Pero dejando al margen este periodo, la normatividad de la Constitución ha sido constantemente puesta entredicho, pudiendo afirmarse en la actualidad que ha perdido una parte importante de su propia identidad para acercarse peligrosamente a la categoría de las Constituciones nominales.

La realidad en la que nos encontramos, y la combinación que resulta de la falta de madurez de nuestra democracia —excesivamente joven aún- con los retos a los que prácticamente desde sus inicios, de forma simultánea, se enfrentaba — la globalización y la realidad de una teoría del poder mediatizada por la gobernanza multinivel, fundamentalmente- explican la atención al principio de lealtad. Un estudio que se intenta llevar a cabo desde un planteamiento que desecha de antemano todo intento de fe incontrolada y ciega en un sistema político, rechazando cualquier tipo de esencialismo, pero que supone al tiempo el intento de dar contenido a un principio que ofrezca unas pautas para hacer sólido un pacto constitucional comprometido, duradero pero eficaz, a la vez que paulatinamente construido.

La lealtad constitucional no parte, en efecto, de la nada. Sirve al objetivo de lograr la plenitud de la Constitución, se conecta con la idea de la necesaria construcción de consenso (o en realidad, consensos) que están en su base, y se afianza con determinados elementos estructurales de la teoría constitucional misma: el principio democrático, la supremacía constitucional en perspectiva multinivel, y la doble dimensión formal/ material de la Constitución. La lealtad se convierte, de este modo, en el punto de engarce entre el derecho y la política, y entre la ley y la democracia, como caras de una misma moneda que pierden todo sentido si no van unidos.

\section{ORÍGENES Y EVOLUCIÓN DEL PRINCIPIO DE LEALTAD CONSTITUCIONAL}

El Diccionario de la Real Academia de la Lengua define la lealtad a partir de tres acepciones: "1. Cumplimiento de lo que exigen las leyes de la fidelidad y las del bonor y hombría de bien ${ }^{2}$. 2. Amor o gratitud que muestran al hombre algunos animales, como el perro y el caballo. 3. Legalidad, verdad, realidad». Y a su vez la fidelidad, término que la RAE utiliza como sinónimo de lealtad, se entiende como "1. La observancia de la fe que alguien debe a otra persona. 2. Puntualidad, exactitud en la ejecución de algo» ${ }^{3}$. Aunque las acepciones de la RAE no se introducen en el ámbito de las ciencias jurídicas ni polí-

2 Aquí es oportuno recordar, por obvio, que debería eliminarse la identificación que la DRAE hace de la lealtad con el sexo masculino a través de dicha expresión (hombría de bien como probidad y honradez), pues implica que en el imaginario colectivo determinadas cualidades, y con ellas la lealtad, no son propias o no identifican al sexo femenino.

3 En cualquier caso, no puede dejar de resultarnos sorprendente que sea ésta una virtud que se predique de los animales, pero que sin embargo la RAE no profundice en una definición más orientada al comportamiento de los seres humanos. 
ticas, es fácil deducir de ellas, como sí pone en evidencia la Enciclopedia Británica, tanto un sentimiento de devoción, adhesión y respeto a determinados compromisos, principios, o valores establecidos en una comunidad, como hacia las personas mismas que forman parte de un proyecto político común máxime si aquellas tienen la misión de realizar dichos compromisos ${ }^{4}$. Y además, tanto en su consideración global, en tanto sociedad integrada en un mismo proyecto, como en particular, hacia quienes lideran dichos compromisos entendidos como comunes. La Constitución va más allá del mero texto y de su simple consideración como norma jurídica suprema, pero sin que exista necesidad alguna de acudir a planteamientos de derecho metapositivo situados fuera de la realidad socio-política y de nuestra cultura jurídica, ni tampoco de considerar la Constitución como un nuevo derecho natural ${ }^{5}$. Se trata por tales motivos, de que ésta sea una norma «viva», al tiempo que se «vive» en ella.

El término proviene del latín «legalis», que significa «respeto a la ley», y se traduce en cualidades como la nobleza, la rectitud, la honradez y la honestidad, permitiendo afianzar relaciones sociales sustentadas sobre vínculos sólidos de confianza, de tal forma que, de un modo casi automático, ello genera en una comunidad una cultura de respeto simultáneo hacia lo común y hacia lo particular. La lealtad parece exigir, no una devoción ciega, simbólica ni irracional, sino el trabajo constante por el compromiso de defensa de aquello y aquellas personas en las que una comunidad cree, de tal modo que el conocimiento y la cultura socio-política se convierten en elementos inescindibles de la lealtad. Porque la Constitución no es solo un orden jurídico sino expresión de una situación cultural en desarrollo ${ }^{6}$. Lo contrario, pues, a la lealtad es el engaño, la traición, el desprecio o menosprecio, e incluso la ignorancia.

Lo anterior se conecta con la polémica expresada a través del diálogo mantenido entre Kant y Constant sobre la posible existencia de un deber incondicionado de decir siempre la verdad 7 , y que parece más vivo que nunca a la luz de la realidad política y jurídica actual. Un debate que en realidad ha representado una inestimable aportación a la compleja —y parece que imposible — respuesta que dan los sistemas políticos

${ }^{4}$ La definición que nos da la Enciclopedia Británica de 1911 hunde sus raíces en el hecho histórico de la lealtad hacia los monarcas, al referirse a la «adhesión al soberano o gobierno establecido del país de uno», o a la «devoción personal y reverencia al soberano y a la familia real». La lealtad se entendería, pues, en el sentido feudal de fidelidad de quien cumple con la ley y no se sitúa al margen o fuera de la misma.

5 Tal es la unión entre Constitución y realidad social o política en la que, como afirma Häberle, el elemento valorativo del Derecho constitucional ha generado una «cultura política» o, incluso más acertadamente, una «cultura constitucional» que permite afirmar que la Constitución no es sólo norma sino también «expresión de un estado de desarrollo cultural, medio de autorrepresentación cultural de un pueblo, espejo de su patrimonio cultural y fundamento de sus esperanzas». P. HäBERLE, «La «Teoría de la Constitución como ciencia cultural» en el ejemplo de los cincuenta años de la Ley Fundamental», en F. Balaguer Callejón (Coord.), Derecho Constitucional y Cultura. Estudios en homenaje a Peter Häberle, Tecnos, Madrid, 2004, p. 25

6 P. HäBerle, «La Ciencia Jurídica Europea como Ciencia de la Cultura», ReDCE, n. ${ }^{\circ} 27,2017$.

7 I. KAnt, B. Constant, ¿Han derecho a mentir? La polémica Immanuel Kant-Benjamin Constant sobre la existencia de un deber incondicionado de decir la verdad, Tecnos, Madrid, 2012. 
con serias dificultades para construir categorías y principios generalmente aceptados. En el fondo, se trataba de poner en evidencia el valor que tienen dichos principios, como se elaboran, y hasta qué punto son eficaces para dar soluciones a los problemas cotidianos. Así, frente a Kant, que lucha por una sociedad ideal, con una verdad superior y auténtica, se situaba Constant, realista y pragmático para quien la puesta en práctica del ideal kantiano — el deber de decir la verdad— necesita de su conexión con principios intermediarios que permitan su definición y lo hagan aplicable para ser real. Sostenía Kant que «El mayor ataque que puede serle hecho al deber del hombre hacia sí mismo, considerado solamente como ser moral (la humanidad en su persona), es lo contrario de la veracidad: la mentira»; porque «la mentira es rechazo y (...) la aniquilación de la propia dignidad del hombre» y porque la ausencia de veracidad haría imposible los contratos y el derecho mismo. Por tales razones reprobable en sí misma. Y especifica, pues, que «la veracidad en las declaraciones se llama también lealtad, cuando se trata de promesas, probidad y, en general, buena fe». A ello replicaba Constant señalando que, en efecto, «es un deber decir la verdad. El concepto de deber es inseparable del concepto de derecho. Un deber es aquello que corresponde en un ser a los derechos del otro. Donde no hay ningún derecho, no hay ningún deber. Por consiguiente, decir la verdad es un deber, pero solamente en relación a quien tiene el derecho a la verdad. Ningún hombre, por tanto, tiene derecho a la verdad que perjudica a otros». Con esta afirmación, sin embargo, y tal y como sostiene este autor, lejos de rechazar el principio kantiano, un brillante Constant propone definir el principio, descubrir su relación con otros principios y con ello su puesta en práctica eliminando los inconvenientes que lo hacen inaplicable.

El principio de lealtad nos lleva, en definitiva, a los orígenes mismo de la teoría del poder desde posicionamientos que han de servir, asimismo, a la gobernanza multinivel. Y de ahí la necesidad de una revisión teórica de nuestro pensamiento político que permita el apoyo en quienes llevan a cabo planteamientos amables a posturas colaborativas, o incluso para poner de manifiesto posicionamientos contrarios a aquellas.

La postura decisionista de Schmitt, de hecho, puede servir para poner de relieve la deriva hacia la que caminan diversos sistemas políticos en los últimos años, indagando en los debates que dieron lugar al modo en que concibe la política este autor en su relación con el derecho, y poniendo en evidencia una postura que parece alejarle de la norma de lealtad propia del constitucionalismo contemporáneo.

Señalaba este autor, en una fase crítica para Alemania, que «la mera posesión del poder estatal produce una plusvalía política adicional, que viene a añadirse al poder puramente legal y normativista, una prima superlegal a la posesión legal del poder legal y al logro de la mayoría». Con esta prima, que procede de situaciones «incalculables e imprevisibles» —en una afirmación, ciertamente peligrosa para el Derecho constitucional-, decía, se consiguen tres ventajas: «la interpretación arbitraria, la presunción de legalidad y la ejecutividad inmediata». Con este planteamiento, Schmitt ponía en jaque la concepción racional-normativa del derecho 
pero creemos que también el conjunto de factores sociales, económicos y políticos a los que debe abrirse cualquier texto constitucional, minusvalorando la intensa relación que debe existir entre derecho y política.

Consciente, además, de que se trata de justificar su postura puramente decisionista, casi desnuda de todo vestigio jurídico-político, colocaba a la justicia en un plano secundario, señalando que «en una competición de velocidad entre el ejecutivo y la justicia, esta llegaría casi siempre demasiado tarde, aún cuando se pusiese en sus manos el eficaz instrumento de poder dictar disposiciones y decretos provisionales, en los casos políticos interesantes».

Pues bien, a pesar del tiempo transcurrido, este debate parece más vivo que nun$\mathrm{ca}^{8}$. Y ello porque el constitucionalismo actual —en su inevitable vertiente multinivel- parece enfrentarse con derivas gubernamentales e intergubernamentales, donde legisladores y jueces, lejos de ser los defensores del pluralismo y de la aplicación de la norma a la luz de los derechos de la ciudadanía, se ven obligados a ejercer un papel de instancias legitimadoras de decisiones adoptadas con anterioridad fuera de las instancias principalmente orientadas a la puesta en común y resolución de los conflictos sociales. Y todo ello en base a una supuesta (falsa) «lealtad» e integridad de esa Constitución misma, bien para defenderla a ultranza, bien para desecharla porque ya no responde a las expectativas imaginadas. Con ello se hace realidad el planteamiento schmittiano, para quien la Constitución deja de ser norma y se basa en un acto de voluntad, en un mandato o en una decisión de un soberano, basado a su vez en una decisión anterior y superior — muchas veces colectiva y abstracta- a la misma Constitución escrita. Frente a ello, Kelsen fundamentará el derecho en las propias normas jurídicas, sustentándose unas a otras, hasta llegar a la última, la «norma hipotética fundamental» $\mathrm{o}$ «supuesta» que debe presuponerse para la completa validez del ordenamiento jurídico y que implica un deber de comportamiento acorde a la Constitución misma, encajando de este modo la realidad con el derecho?

Pero como es bien conocido, este autor limitó el contenido material esencial de la Constitución al «Derecho constitucional procedimental organizativo del poder», desde la consideración de la Constitución a partir de su función estricta de mecanismo dispuesto para la articulación y organización de los poderes estatales, y técnica de limitación sobre aquéllos ${ }^{10}$. En sus propias palabras, «la Constitución constituye un

${ }^{8}$ J.L. Cascajo Castro, «Constitución y Derecho Constitucional: apuntes con motivo de un aniversario", Revista Jurídica de Castilla y Leon, n. ${ }^{\circ}$ extraordinario, 2004, pp. 17-18.

9 H. Kelsen, Teoría pura del Derecho, Eudeba, Buenos Aires, 1979, pp. 15-16.

${ }^{10}$ Con el claro propósito de asegurar la primacía parlamentaria y la democracia, con una Constitución absolutamente formal y procedimental, y un juez constitucional limitado a la estricta función de aplicar reglas. L. Prieto SANCHís, «Constitución y Parlamento», Parlamento y Constitución. Anuario, n. ${ }^{\circ}$ 5, 2001, pp. 20-21. Por ello, dirá este mismo autor en otra obra, el modelo de justicia kelseniano consecuente supondrá «la culminación del Estado de Derecho europeo, lo más lejos que éste podía llegar desde su concepción de la soberanía estatal y de la Constitución como orden jurídico del Estado, no sobre el Estado» (en «Presupuestos ideológicos y doctrinales de la justicia constitucional», en la obra del mismo autor Justicia Constitucional y Derechos Fundamentales, Trotta, Madrid, 2003, p. 80). 
principio donde se expresa jurídicamente el equilibrio de fuerzas políticas en un momento determinado, es la norma que regula la elaboración de las leyes, de las normas generales en ejecución de las cuales se ejerce la actividad de los órganos estatales, tribunales y autoridades administrativas. Esta regla de creación de las normas jurídicas esenciales del Estado, de determinación de los órganos y del procedimiento de la legislación, forma la Constitución en sentido propio, originario y estricto del término» ${ }^{11}$. Un planteamiento ciertamente comprensible, idealista, propio de un momento histórico en el que la inestabilidad política, social y económica lo podía requerir.

La evolución de nuestro constitucionalismo en estos últimos cuarenta años ha introducido, ciertamente, el conflicto social y los valores propios de las Constituciones democráticas de la posguerra: los derechos en sus diferentes vertiente y un Estado social y Democrático como fórmula informadora y fórmula política, intentando superar constantemente la idea de que aquellos son fórmulas abstractas y vagas. Pero en el fondo, sin dejar de estar presente el debate entre el decisionismo schmittiano y el normativismo kelseniano. Tras cuarenta años, de hecho, la realidad jurídica, política y social parece mostrar unos contornos constitucionales necesitados de equilibrios, acordes a la norma de lealtad y a los fundamentos que están en su base, pues ni es posible confiar el destino del pacto constitucional a la mera suma de voluntades ciudadanas, ni podemos seguir pensando que una clase política coyuntural posee una legitimación absoluta para decidir el destino de dicho pacto al margen de la sociedad misma. Una democracia y una constitución identitaria obligan a recuperar los frenos y contrapesos que unen al derecho con la política: con una representación política que dialoga constantemente con la ciudadanía, unas instituciones que asumen de modo leal el papel que les corresponde en el sistema sin hacer dejación de funciones o llevar a cabo excesos de jurisdicción, y una ciudadanía responsable e implicada. Porque ya no hay «armonías preconstituidas», como nos dijo Fioravanti1"; aunque esas armonías, en realidad, no existieron nunca y se presentaban como ficticias. En el fondo, diríamos que eran más bien desarmonías silenciadas.

Parece, sin embargo, que las mayorías políticas, que deben ejercer una labor de liderazgo responsable y eslabón entre los diversos intereses en juego, descuidan la tarea de socialización política que les corresponde por pertenecer, en su base, más allá

11 H. Kelsen, La garantía jurisdiccional de la Constitución (La justicia constitucional), (traducción de R. Tamayo y Salmorán), Universidad Nacional Autónoma de México, México, 2001, p. 21 (el texto originario data de 1928, y fue publicado en la Revue de Droit Public et de la Science Politique en France et a l'étranger). Desde este punto de vista, se explica que, como afirma Martínez Sospedra, la Constitución Austriaca de 1920 sea un texto cuyo contenido está formado por normas organizadoras y habilitadoras de los poderes públicos, donde falta un catálogo de derechos y una referencia a normas relativas a los valores básicos del sistema constitucional. (Vid. "Constitución y Justicia Constitucional. Sobre las relaciones entre el concepto de constitución y el sistema de justicia constitucional», Revista General del Derecho, nos 634-635, 1997, pp. 8724 ss.

${ }^{12}$ M. Fioravanti, «La Constitución democrática del Novecento: génesis y perspectivas, en R. TuR Ausina (Dtora.), M.A. Calabuig Puig, F. Sanjuán Andrés (Coord.), Poderes Públicos y Privados ante la regeneración constitucional democrática, Dykinson, Madrid, 2016. 
de la institución en que se encuentran, a organizaciones políticas de reconocimiento constitucional, los partidos políticos. Lejos de embarcarse sin embargo en esta tarea, no ha resultado extraño que se vieran tentados a personificar el poder mismo del ente público como unidad artificiosa, en una manifiesta postura desleal con el sistema mismo y, en resumidas cuentas, con el pacto constitucional de convivencia.

Lo expuesto, sin embargo, no se identifica sólo y necesariamente con el último de los conflictos territoriales que vivimos, el del Estado central con Cataluña, cuyos orígenes son ya lejanos. La realidad es mucho más compleja y arranca de la génesis de la Constitución misma y de los desarrollos que sus principios y valores han experimentado; quizá de la falta de «manutención constitucional» a que suele aludir la doctrina italiana ${ }^{13}$, y que implica una atención constante a la actualidad del texto, sea o no a través de una reforma constitucional. Pero también se debe a las dificultades por encajar nuestro sistema político en las dos verdades europeas (Unión Europea y Consejo de Europa), que a su vez beben de las propias vicisitudes jurídico-políticas de otros países, las cuales tienen un claro efecto de contagio sobre el resto. Una especie de círculo vicioso que la globalización no hace más que ampliar. En cualquier caso, la lealtad exige aunar, en palabras de Grimm, la estabilidad del pacto social, con el control de los cambios, pero también con la permanente actualidad del texto ${ }^{14}$.

Proyectado lo anterior sobre el propio funcionamiento jurídico-político de una comunidad, la historia del derecho — o más si cabe la historia del derecho público—, han puesto en evidencia que antes de inventar ninguna categoría, institución o principio, conviene reinventar o reajustar las existentes (partiendo además de las acepciones comunes de las palabras, como hicimos con anterioridad).

Y así debe hacerse también con el principio de lealtad: clásico principio del derecho privado, utilizado como principio que articula las relaciones entre las Administraciones Públicas (derecho administrativo) ${ }^{15}$, que se proyecta específicamente sobre el personal al servicio de la Administración ${ }^{16}$, y de implantación particular en las

13 F. LANCHESTER, Le istituzioni costituzionali italiane tra globalizzazione, integrazione europea e crisi di regime, Giuffrè, Milano, 2015; C. Fusaro, D. Oliver (a cura di), How Constitutions change. A comparative study, Oxford, Hart, 2011.

14 D. Grimm, Constitucionalismo y derechos fundamentales, Trotta, Madrid, 2006.

15 F. Sosa Wagner, M. Fuertes López, «El principio de lealtad institucional», en VV.AA., Los principios jurídicos del derecho administrativo, La Ley, Madrid, 2010.

${ }^{16} \mathrm{La}$ lealtad derivaría de las funciones que el funcionariado desarrolla, en muchas ocasiones privilegiadas y extraordinarias, y que se traducen en una garantía de actuación a favor del orden constitucional como requisito de acceso, una vinculación positiva con el orden constitucional, y un deber de cumplimiento en todo momento. Por lo tanto un requisito para la adquisición de la condición de funcionario pero al tiempo un deber genérico siempre presente en su actividad y que se concreta en la adecuación a la legalidad, el deber de neutralidad e independencia política, el respeto a la dignidad institucional, al principio de igualdad, y a los particulares en ejercicio de sus derechos, y las consecuentes obligaciones. P. Nevado-BAtalla, «El sistema de obligaciones del personal y autoridades al servicio de la administración en el ordenamiento jurídico español: especial referencia al principio de lealtad a la Constitución», Iustitia, diciembre 2011, pp. 139 ss. 
cuestiones territoriales (la idea del bundestreue alemán o principio de lealtad federal). En efecto, el principio no es nuevo y deberemos partir de diversas realidades jurídicas evidentes en el ámbito del derecho.

Desde estos ámbitos — ceñidos a la disciplina del derecho privado, y utilizado en el ámbito territorial administrativo_- se ha tratado de articular un principio —el principio de lealtad constitucional—, que no se recoge explícitamente en la Constitución pero que cabe deducir implícitamente de los presupuestos y objetivos que impregnan los sistemas políticos constitucionales, y que sí tiene una mención en otras normas. De hecho, el principio de lealtad institucional aparece como uno de los principios que rigen las relaciones entre las Administraciones, en los arts. 3.1 y 140 de la Ley 40/2015, de 1 de octubre, de Régimen Jurídico del Sector Público ${ }^{17}$, y en diversos Estatutos de Autonomía ${ }^{18}$, y por su parte alude también a ello el art. 55 de la Ley de Bases de Régimen Local referido a los principios que rigen las relaciones interadministrativas ${ }^{19}$. No obstante, la Constitución sí parece mostrar cierto compromiso con la filosofía que inspira el principio de lealtad constitucional en diversas partes del Preámbulo, cuando apela al deseo de establecer la justicia, la libertad y la seguridad

${ }^{17}$ En el art. 3.1. e) se recoge la lealtad institucional junto con la buena y la confianza legítima como principio general, y en el art. 140 se vuelve a mencionar en tanto principio que rige las relaciones interadministrativas. En tal sentido, resulta en cierto modo paradójico que esta norma no lleve a cabo un mayor desarrollo cuando sí lo realizan algunos Estatutos, como veremos.

18 El Estatuto de Autonomía de Cataluña de 2006 señala en su art. 3.1 que «Las relaciones de la Generalitat con el Estado se fundamentan en el principio de la lealtad institucional mutua»; se menciona de nuevo en el art. 201.2 referido a los principios que rigen la Hacienda Local; y el art. 209 centrado específicamente en la lealtad institucional, dentro del título dedicado a la financiación de la Generalitat, que lo define del siguiente modo: «1. De acuerdo con el principio de lealtad institucional, se valorará el impacto financiero, positivo o negativo, que las disposiciones generales aprobadas por el Estado tengan sobre la Generalitat o las aprobadas por la Generalitat tengan sobre el Estado, en un periodo de tiempo determinado, en forma de una variación de las necesidades de gasto o de la capacidad fiscal, con la finalidad de establecer los mecanismos de ajuste necesarios. 2. Ambas Administraciones se facilitarán mutuamente el acceso a la información estadística y de gestión necesaria para el mejor ejercicio de sus respectivas competencias, en un marco de cooperación y transparencia». En parecido sentido, o incluso con mayor énfasis, la lealtad institucional interterritorial es mencionada en los arts. 90, 93, 133, 175.2 f), 183.1 y 5, y 219 del Estatuto de Autonomía andaluz de 2007.

19 Así, en su redacción dada por la Ley 27/2013, de 27 de diciembre, de racionalización y sostenibilidad de la Administración local: «Para la efectiva coordinación y eficacia administrativa, la Administración General del Estado, así como las Administraciones autonómica y local, de acuerdo con el principio de lealtad institucional, deberán en sus relaciones recíprocas: a) Respetar el ejercicio legítimo por las otras Administraciones de sus competencias y las consecuencias que del mismo se deriven para las propias; b) Ponderar, en la actuación de las competencias propias, la totalidad de los intereses públicos implicados y, en concreto, aquellos cuya gestión esté encomendada a otras Administraciones; c) Valorar el impacto que sus actuaciones, en materia presupuestaria y financiera, pudieran provocar en el resto de Administraciones Públicas; d) Facilitar a las otras Administraciones la información sobre la propia gestión que sea relevante para el adecuado desarrollo por éstas de sus cometidos; e) Prestar, en el ámbito propio, la cooperación y asistencia activas que las otras Administraciones pudieran precisar para el eficaz cumplimiento de sus tareas». 
y promover el bien de cuantos la integran, de garantizar la convivencia democrática dentro de la Constitución y de las leyes conforme a un orden económico y social justo, de promover el progreso de la cultura y de la economía para asegurar una digna calidad de vida, y de establecer una sociedad democrática avanzada ${ }^{20}$. En cualquier caso, pese a la notable importancia de algunos estudios ${ }^{21}$, compartimos con estos la idea de que nuestra doctrina no ha llevado a cabo un análisis teórico-jurídico de la propia categoría de lealtad constitucional, con carácter autónomo, sin desechar la posibilidad de su construcción jurídica, y más allá de la propia noción de supremacía y sujeción constitucional.

Por lo demás, el Tribunal Constitucional se pronunció sobre la lealtad constitucional ciñendo su significado a la idea de sujeción o acatamiento a la supremacía constitucional. En tal sentido, la STC 122/1983 (reiterada posteriormente en las SSTC 119/1990 y 42/2014), relativa al deber de diversos representantes del Parlamento gallego de jurar o prometer «acatar y guardar fidelidad a la Constitución y al Estatuto». En dichas resoluciones el Tribunal dispuso que dicho deber no implica adhesión ideológica alguna al contenido de ambas normas, sino un acatamiento a las reglas democráticas y al ordenamiento, y sin que quepa en nombre de la lealtad llevar a cabo restricciones inadmisibles a los derechos. Esta doctrina, sin embargo, parece haber resultado insuficiente e incluso en cierto modo contradictoria con la norma de lealtad. Y ello porque, como advertía Jiménez Campo, la libertad de pensamiento implica autonomía mientras la lealtad —-más allá del respeto a los procedimientos democráticos, sobre lo que no cabe dudar-, supone compromiso por parte de una pluralidad de sujetos sobre un objeto, y del que derivan obligaciones mutuas $^{22}$. Añade que efectivamente la lealtad es más que una sujeción a la norma, pues sobre ello ya se pronuncia el art. $9 \mathrm{CE}$, sin que implique tampoco limitarse a una mera adhesión emocional ni a una identificación incondicional, petrificada y perpetua a la Constitución. Y sostiene, pues, que «la lealtad constitucional es una actitud previa que todos deben —o al menos pueden — tener ante la Constitución, sobre todo en los casos de discrepancia con sus contenidos o con otras lealtades», una actitud ponderativa y abierta a la participación en el debate constitucional que desecha interpretaciones e intervenciones oportunistas e interesadas en torno a aquella.

${ }^{20}$ No obstante, es complejo reducir el debate a la búsqueda de la norma de lealtad constitucional en la Carta Magna a partir de un posicionamiento positivista estricto, negando la clásica distinción entre Constitución material y formal, pues como señalaremos con posterioridad, esta norma requiere de una labor de conceptualización más compleja, sin caer en planteamientos metapositivos alejados de la realidad social. De esto advierte Punset en «Lealtad constitucional, limitación de derechos y división de poderes», Repertorio Aranzadi del Tribunal Constitucional, n. ${ }^{\circ}$ 16, 2002, pp. 13 ss.

21 L. Álvarez Álvarez, El principio de lealtad constitucional, Centro de Estudios Políticos y Constitucionales, Madrid, 2008.

${ }^{22}$ Vid. en tal sentido, la crónica de A. GonzÁlez Alonso, «La lealtad constitucional. La Constitución como orden de valores o como procedimiento", Revista de Estudios Políticos, n. ${ }^{\circ} 120,2003$, que recoge sintéticamente las intervenciones de un curso celebrado en Alicante en octubre de 2002, dirigido por el profesor Solozábal. Sobre la ponencia de Javier Jiménez Campo, pp. 336-337. 
Y para ello, se necesitará asumir que la Constitución tiene «un sentido político» ${ }^{23}$ y es una norma para resolver los conflictos sociales, los cuales se integran de modo natural en la vida cotidiana.

El principio de lealtad tiene, pues, un carácter complejo, y su objetivo es el de hacer más sólido el marco constitucional, con el refuerzo de los compromisos que el mismo implica, sirviendo a la eficacia de la Carta Magna como un todo.

\section{FUNDAMENTO Y JUSTIFICACIÓN CONSTITUCIONAL DE LA LEALTAD CONSTITUCIONAL}

El principio de lealtad parte en el ámbito jurídico-constitucional de ciertas premisas básicas relacionadas con el concepto mismo de Constitución: qué es, qué implica tener una Constitución, y qué requiere la misma para afianzar sus postulados. Se ha sostenido, de hecho, como punto de partida, que la lealtad constitucional se traduce en el ámbito de la ciencia del Derecho constitucional en una norma plasmada expresa o tácitamente en los textos constitucionales, que a modo de mandato, permiso o prohibición, y asumiendo la estructura de principio o de regla, trataría normativamente de dar eficacia al contenido de uno o varios principios estructurales. $\mathrm{Y}$ asimismo, que dicha norma de lealtad encontraría su fundamento en tres presupuestos teórico-normativos: en el principio democrático, en la supremacía constitucional reconfigurada a nuestro juicio desde la dimensión multinivel del sistema político, y en la positividad ${ }^{24}$. La lealtad constitucional tiene, por todo lo anterior, un carácter poliédrico y complejo que deriva, precisamente, de la configuración misma de la Constitución como compromiso político al tiempo que norma aglutinadora de diversos intereses que confluyen en un pacto social a través de la generación de un consenso básico.

Así, en primer lugar, el principio democrático como fundamento teórico de la norma de lealtad exige considerar su contenido. El mismo llega más lejos de las propias ideas de participación ciudadana y pluralismo, e implica no sólo legitimidad democrática en el origen sino en el funcionamiento mismo de los poderes públicos y privados ${ }^{25}$. En particular, para atender al respeto de la esencia del pacto constitucional, la transparencia, la igualdad, la solidaridad, la responsabilidad en la toma de decisiones, la bidireccionalidad entre agentes que intervienen, e incluso, la idea misma de supranacionalidad constitucional. Ello supone que, a partir de la interpretación anterior, la plenitud del principio democrático desde la norma de lealtad no podría llegar al punto — en aras de la eficacia reclamada_-, de que los procedimien-

${ }^{23}$ M. Aragón Reyes, «Sobre las nociones de supremacía y supralegalidad constitucional», Revista de Estudios Políticos, n. ${ }^{\circ}$ 50, 1986, p. 10.

${ }^{24}$ L. Álvarez Álvarez, El principio de lealtad... cit., p. 13 y 32.

25 E. Álvarez Conde, «El Derecho Constitucional y la crisis», Revista de Derecho Político, n. ${ }^{\circ} 88$, 2013, pp. 86 ss. 
tos democráticos pudieran llegar a suprimir la democracia misma, pues se trataría de un planteamiento que estaría convirtiendo al demos en un poder constituyente en permanente acción. El principio democrático se encuentra llamado a convivir, parece que en excesivas ocasiones, con el principio monárquico, por lo que aunque el gobernante tiene una legitimidad de origen, corre el riesgo de caer en el puro pragmatismo derivado de la eficacia y eficiencia con que aplica su dirección política. Sin embargo, ante ello el constitucionalismo democrático de nuestros días está llamado a intentar que el principio democrático venga a ocupar cada vez más espacios y ámbitos — desapareciendo el principio monárquico-, tratando de convertir la obediencia a la Constitución en adhesión voluntaria, permanentemente construida, y razonable y crítica al tiempo ${ }^{26}$.

En segundo lugar, la pretensión de dotar de indisponibilidad a las normas constitucionales desembocaría no sólo en la invalidez de aquellas otras contrarias a la Constitución - y con ellas las normas a las que ésta última les confiere también la función de estructurar la creación normativa en los niveles superiores del ordenamiento- , sino también en la pretensión misma de eficacia de ésta última. Y ello, porque la Constitución trata de conseguir una regulación estable y comprometida para la convivencia humana, sobreponiéndose a las decisiones de los poderes constituidos ${ }^{27}$.

Finalmente, es el fundamento de la positividad el que mayores problemas ontológicos nos plantea. Y ello porque, aún reconociendo que la idea de positividad permite a la democracia, como presupuesto que es de la lealtad, conseguir la función diferenciadora a la que aspira —-frente a otros órdenes: moral, social, político— ${ }^{28}$, no parece que para ello resulte necesario — ni viable — un deslinde tajante entre la norma y la realidad, entre el deber ser y el ser. La positividad habría de ser interpretada, a nuestro juicio, de un modo relativo, y no en términos estrictos, pues la dogmática material — frente a la formal_ de la Constitución no necesariamente lleva a cabo una confusión de planos, sino más bien una necesaria integración de los mismos. Y ello porque estamos obligados a admitir que la norma de lealtad tiene que responder a un concepto de Constitución que, por definición, se halla integrado por normas jurídico-positivas fusionadas con la realidad material del momento. La Constitución «crea jurídicamente a la sociedad ${ }^{29}$; y es precisamente este momento creador el que nos lleva a preguntarnos sobre la ordenación de la vida en común y el hecho de la obediencia al poder.

No ha sido infrecuente, no obstante, escuchar que la dogmática material de la Constitución produce inseguridad y genera una notable ambigüedad, pues en último término implica enfrentarse a la pregunta de quién ha de identificar los contenidos

${ }^{26}$ N. Bobbio, N. Matteucci, G. Pasquino, Diccionario de Política, Siglo XXI, México, 2005.

27 L. Álvarez Álvarez, El principio de lealtad... cit, pp. 34-35.

${ }^{28}$ Ibidem, p. 52.

29 A. Garrorena Morales «Cuatro tesis y un corolario sobre el Derecho Constitucional», Revista Española de Derecho Constitucional, n. ${ }^{\circ}$ 51, 1997, p. 39. 
constitucionales fundamentales al situar estos fuera de la norma escrita. Pero no es menos cierto que los planteamientos formalistas producen, al menos, tanto o más incertidumbre, si se pretenden desconectadas del contexto social y de la construcción paulatina de la Constitución que resulta conveniente. De hecho, el gran reto pendiente de nuestro constitucionalismo contemporáneo - fundamentalmente en el caso del modelo continental_- es posible que no sea tanto la definición de la propia fundamentalidad constitucional, como el quien, el cómo y a través de qué mecanismos lograr el mismo, donde las dificultades en estos últimos casi cuarenta años de Constitución son evidentes. Valgan como ejemplo, las resistencias a una reforma constitucional o a una revisión o reestructuración —aunque no se siguiera la vía de la reforma - del modelo territorial de Estado. La procedimentalidad tiene, más que nunca, un significativo contenido sustancial que no debe ser menospreciado.

De hecho, desde una definición epistemológica, lo constitucional abarcaría modos de expresión que irían más allá del texto de la Constitución misma. No tendría solo una dimensión jurídica sino también político-social. Y se articularía como un proceso de largo recorrido, sin que pueda decirse que se construye de una sola vez y para siempre.

Aunque la Carta Magna es, afortunadamente, norma, tampoco es posible obviar, como señalaba Aragón, «el sentido político de la Constitución» ${ }^{30}$. Si dejamos a un lado los aspectos históricos, fácticos, antropológicos o políticos de las normas constitucionales, no llegaremos a comprender la esencia de la Constitución. Y ésta se nos hará lejana e inaccesible, pues nace, vive, y se desarrolla en la realidad cotidiana. De hecho, disociar lo jurídico de lo social y de lo político resulta más propio del constitucionalismo liberal, cuando se intentaba sustraer a lo jurídico de las tensiones políticas que luchan por el control por el poder y la soberanía: «El poder del Derecho pretende ser, así, el de una normativa independiente de las luchas políticas, que intenta desarrollar una función arbitral, imposible sin embargo por las propias condiciones de un discurso político planteado en términos de confrontación global» ${ }^{31}$. Por las mismas razones, disociar lo político de lo jurídico-constitucional supone perder de vista la labor de «unificación» y «cohesión» que desempeña el Derecho constitucional; la noción misma de pacto constitucional. A nadie se le escapa, en tal sentido, que ciencia política y derecho constitucional son dos caras de la misma moneda, y que la centralidad de ambas disciplinas — cuando no la fusión en múltiples momentos y acontecimientos de la vida - es necesaria. Pretender sustituir una por la otra — sobre todo en los últimos tiempos donde las personas expertas en Derecho constitucional parecen ocupar un lugar secundario frente a la Ciencia política- no es sino una visión sesgada de nuestra realidad, aparte de que supone perder de vista nuestros últimos siglos de historia.

30 M. Aragón Reyes, «Sobre las nociones de supremacía y supralegalidad constitucional», Revista de Estudios Políticos, n. ${ }^{\circ}$ 50, 1986, p. 10.

31 F. Balaguer Callejón, Manual de Derecho Constitucional, Tomo I, Tecnos, Madrid, 2016, p. 35. 
Pero también es posible que si el formalismo representa un riesgo para el derecho, el antiformalismo se traduzca en un no-Derecho. Por ello se trata de que política y derecho cojan la senda de la coordinación y el diálogo constructivo. Porque la separación de ambos ámbitos, o la dejación de funciones que pueda realizar uno de ellos a favor del otro, pueden suponer - y ejemplos no nos faltan en los últimos tiempos-, o bien la anarquía descontrolada, o bien la represión desde el más puro uso de la fuerza. El proceso de acomodamiento entre legalidad y política es absolutamente imprescindible en un régimen constitucional. No hay, de hecho, régimen constitucional sin este encaje de piezas, el cual conduce en efecto a la plena vigencia del «principio democrático», que está presente en la Constitución aunque no lo diga expresamente.

En resumidas cuentas, el Derecho Constitucional no puede reducirse a la dogmática, al positivismo desnudo, pues la norma primaria tiene un contenido material complejo que se traduce en la garantía de la libertad, la igualdad y el pluralismo, la libre elección de quienes nos gobiernan, la limitación del poder político y, en último término, la dignidad humana. El concepto de Constitución es, en consecuencia, pluridimensional, pues «comparte con el Estado el destino de que su propio concepto es unitario, uno de los huesos más difíciles de roer de la Ciencia jurídica» ${ }^{32}$. Seguir manteniendo esa «unidad» a pesar de la dispersión que el reto globalizador y multinivel nos presentan es, precisamente, el gran reto de nuestros días.

A partir de dichas consideraciones, el principio de lealtad constitucional impondría a cada sujeto del sistema jurídico-constitucional el deber de abstenerse de invadir competencias ajenas así como de ejercitar sus propias competencias, funciones y deberes, teniendo en cuenta los efectos derivados de los principios estructurales del ordenamiento constitucional que sus decisiones tendrán en relación con otros niveles institucionales, con la coherencia del sistema jurídico-político, con la fundamentalidad del Estado, y con la libertad e igualdad ciudadana. Se trataría, pues, de una colaboración que se produce mientras se ejercen las tareas propias, lo cual implica hacer compatible el activismo democrático con una cierta «autocontención» evitando, en consecuencia, la sobreactuación, y con el objetivo de contribuir a hacer realidad el patrimonio común constitucional, pues la democracia no es neutra ni aséptica, debiendo producirse constantemente un cierto rearme ideológico del sistema. La lealtad constitucional iría, pues, más allá de una simple actitud pasiva de respeto para traducirse en una vinculación activa al contenido de la Carta Magna misma.

Ahora bien, la norma de lealtad no se traduce exclusivamente en un ejercicio interno e individual de «autocontención», pues desde la naturaleza colaborativa característica de la sociedad, dicha autocontención no es un mero ejercicio individual, sino que se alcanza al tiempo a través de la articulación de instrumentos de retroalimentación, diálogo y negociación precisos.

32 K. Stern, Derecho del Estado de la República Federal de Alemania, Centro de Estudios Constitucionales, Madrid, 1987, p. 202. 
Ello nos introduce en la compleja cuestión de la «democracia militante» que acoge nuestro texto, en el que si bien nuestro constituyente y nuestra doctrina constitucional no llegan a adoptar el modelo alemán que sanciona a «los enemigos» del sistema y opta por limitarse a dejar fuera a «los infractores», ello no supone sin embargo que la Constitución se caracterice por una neutralidad absoluta y por un relativismo total ${ }^{33}$. También nuestro modelo democrático es militante porque, concebido de forma distinta, igualmente defiende los valores que propugna. Una cuestión que no guarda relación alguna con la reforma total de la Constitución, a diferencia de lo que sostuvo el Tribunal Constitucional en la STC 48/2003, pues aquella no es solo norma procedimental, tesis a la que conduce la no consideración de una democracia como militante. Porque en efecto, una democracia no militante o procedimental, es una democracia inerme. La Constitución — como la democracia-, o es militante o no es Constitución —ni democracia-.

Desde estas consideraciones, las posibles deslealtades que puedan sucederse en un sistema político en base a diversas infracciones de la legalidad constitucional que son más que evidentes (e incluso admitidas por los propios infractores) - como ocurre con el independentismo catalán—, no pueden sustanciarse por la vía de nuevas deslealtades articuladas en forma de medidas que impliquen un nuevo recorte y/o sacrificio de los principios estructurales a los que la misma lealtad sirve (principio democrático, positividad y supremacía constitucional).

33 Recuérdese que la noción de «democracia militante» fue también negada doctrinalmente, alegándose para ello que resultaba preferible una «democracia pluralista» en la que la Constitución ejercería un papel de consenso e integración. Se consideraba que así encajaba mejor nuestro sistema con una concepción de la lealtad como proceso lento y sólido de asimilación y profundización de valores democráticos (en tal sentido. M. SALGADO, «Socialización política y lealtad a la Constitución», Revista de Estudios Políticos, n. ${ }^{\circ}$ 97, 1997, pp. 319 ss.). Sin embargo, se ha puesto en evidencia el «relativismo constitucional» a que ha llevado la última opción, lo que implica recuperar el ideal de democracia militante —en la configuración que venimos sosteniendo_ como instrumento más idóneo para una adecuada lealtad constitucional. Vid. al respecto E. Álvarez Conde, A.H. Català i Bas, El derecho de partidos, Cólex, Madrid, 2013; A. Torres Del Moral, «Democracia militante», en VVAA, Derecho Constitucional del siglo XXI, Aranzadi, Pamplona, 2006. En tal sentido, la jurisprudencia constitucional acaecida en las SSTC 48/2003, 5/2004, 31/2009, y 43/2009. Cabe recordar que en fechas recientes, y a raíz del conflicto territorial catalán de octubre de 2017, algunas fuerzas políticas propugnan la posible ilegalización de los partidos independentistas apelando al sostenimiento por los mismos de un discurso contrario a la propia ideología constitucional. En nuestra opinión, sin embargo, la propia configuración de nuestro modelo constitucional, que desecha el modelo alemán de dejar fuera a los enemigos del sistema, impide esta posibilidad. Debe tenerse en cuenta que la Ley Orgánica 6/2002 de Partidos Políticos prevé dicha ilegalización para los partidos cuya actividad implique un apoyo manifiesto al terrorismo. Esto significa que, en primer lugar, se sanciona al infractor y no solo al enemigo; y en segundo lugar, que la norma está prevista para un caso concreto — terrorismo_-, el cual debe ser claramente deslindado del independentismo. El primero, el terrorismo, conlleva per se un atentado a la dignidad de las personas; el segundo, no hasta que se demuestre en actividades concretas que ello es así, y para lo que entonces existe un ordenamiento penal y sancionador con mecanismos suficientes para dar respuesta a la conducta infractora. 
La supuesta «neutralidad» de nuestra Carta Magna no debió nunca identificarse con la falta de cualquier elemento ideológico en la misma, sino con su enérgica capacidad para hacer entrar en el juego constitucional a cualquier tipo de fuerza política. En efecto, de la Constitución no debe desprenderse sino una fuerte «militancia democrática», que implica de hecho la inescindible conexión que debe existir entre legalidad constitucional — con todo lo que ella implica de pacto y compromiso en un proyecto común - y legitimidad democrática —en una sociedad rica pero diversa al tiempo-, máxime si cabe en cuanto los efectos de la globalización y de una nueva era neoliberal generan en la ciudadanía importantes vacíos en valores y principios ${ }^{34}$.

El respeto a la legalidad constitucional tiene su sentido en tanto sirve a la democracia misma y viceversa. Sin embargo, la realidad muestra que una separación entre ambos espacios parece ser resultado de un nuevo liberalismo que empodera a la ciudadanía, convirtiéndola en emprendedora por sí misma, pero que al tiempo elimina la responsabilidad de los entes públicos propia del Estado Social y Democrático de Derecho al renunciar a sus prerrogativas, que son privatizadas y delegadas en la socie$\mathrm{dad}^{35}$. De este modo, la intervención del poder público quedaría reservada a momentos de importantes faltas de respeto a la legalidad, en los cuales la intervención de aquel podría adoptar posicionamientos que corren el riesgo de ser excesivamente rotundos, con el consecuente sacrificio de los postulados democráticos. Lejos, pues, de llevar a cabo una labor de manutención constitucional que implique el encaje de legalidad y democracia de forma paulatina y dialogada, el poder público hace una dejación de funciones que sólo recupera en momentos de crisis extrema, con el riesgo evidente de llevar a cabo una ponderación equivocada de la ley pero también de la democracia.

La infracción de la norma de lealtad constitucional puede implicar en un sistema político la radicalización de las diversas posturas en juego, con la consiguiente polarización de la masa social y la separación entre las líneas que representan la norma y la sociedad misma, que no llegarían de este modo a tocarse nunca. De esta forma, la vuelta al respeto de la lealtad constitucional se presenta excesivamente costosa para los actores del sistema, hasta el punto de que o bien representa un punto de no retorno, o el retorno se presenta excesivamente complejo y lento. En cualquier caso, alguien saldrá sacrificado: la ciudadanía o un sector de la misma y/o algunos representantes políticos o gobernantes. Debe recordarse que los principios estructurales que fundamentan la norma de lealtad llevan a concebir la Constitución misma como una norma de integración y de consensos, y no de meras mayorías. Consensos que no se identifican con la uniformidad, la homogeneidad y la unanimidad, y que no basta con que se produzcan en un momento histórico determinado, pues deben formar parte de la vida cotidiana del sistema político mismo. Se pre-

${ }^{34}$ Vid. sobre este contexto relativo a la crisis del Estado y de la Democracia, Z. BAUman, C. BorDONI, Estado de crisis, Paidós, Barcelona, 2016.

35 Ibidem, pp. 47 ss. 
tende superar la idea de que la política y el derecho se articulan sobre operaciones binarias confrontadas, pues se trata de evaluar la capacidad de integración de los intereses en juego en una norma o en una política pública. Y ello aunque el alcance de dichos consensos no siempre resulte fácil, pues, en muchas ocasiones, incluso responden a factores externos fuera de control de los actores principales. Piénsese en la influencia del movimiento globalizador, o en los procesos de integración en organizaciones supranacionales.

Asimismo, lo anterior esconde una terrible paradoja: que los comportamientos desleales con la Constitución misma llevan a una bucle argumental según el cual, en lugar de volver a la legalidad democrática, esta es necesariamente orillada. En efecto, porque se tiene tendencia a pensar que quien es desleal no estaría legitimado para hacer uso de los instrumentos que la propia legalidad democrática le ofrece, con lo cual la consecuencia inmediata es la separación cada vez más profunda entre el orden constitucional y la realidad social por esa falta de «mantenimiento», precisamente, del pacto constitucional concebido desde la norma de lealtad.

En definitiva, la lealtad constitucional habrá de traducirse en un deber cívico e institucional jurídicamente exigible, de comportamiento y ejercicio competencial, teniendo en cuenta el mantenimiento constante de la idea de comunidad como proyecto diverso pero común. Por ello la lealtad constitucional responde a las cuestiones relativas a quién y cómo hacer realidad los compromisos constitucionales contribuyendo además, en particular, a dar una respuesta al clásico aforismo «Quien controla al controlador? (Quis custodiet ipsos custodes?)». Y para ello quizá deberá cuestionarse el papel que el Estado está llamado a desempeñar — definiendo quien es Estado y con qué alcance- $-{ }^{36}$. Pero la ciudadanía tiene su papel también en ello, aunque la misma no pueda llegar a ser un sustitutivo de las instancias representativas ni de otros poderes, por lo que se tratará de articular el modo en que se logra el objetivo de la identidad constitucional o el sentimiento pleno de identificación de la ciudadanía y los poderes con los principios constitucionales. Ello nos conduce al concepto de soberanía mismo ${ }^{37}$.

36 No olvidemos que para el propio Tribunal Constitucional las Comunidades Autónomas son Estado (STC 12/1995), y que incluso el propio Estatuto de Autonomía de Cataluña de 2006, en una especie de característica petrificación — en este y otros ámbitos — de la jurisprudencia constitucional, así lo dispone en su art. 3, referido al marco político: «1. Las relaciones de la Generalitat con el Estado se fundamentan en el principio de la lealtad institucional mutua y se rigen por el principio general según el cual la Generalitat es Estado, por el principio de autonomía, por el de bilateralidad y también por el de multilateralidad».

37 De hecho, cabría pensar en aquellos momentos en nuestra reciente historia constitucional democrática, en los que una llamada a la ciudadanía a las urnas en dos ocasiones en pocos meses en la fallida legislatura 2015-2016, o ante el conflicto territorial catalán en las elecciones de 21 de diciembre de 2017, no han significado sino depositar en la sociedad una responsabilidad que debió sin embargo ser asumida con anterioridad por quienes nos gobiernan y por los poderes públicos correspondientes, y que la norma de lealtad impone. 
La llamada al principio de lealtad constitucional supone reclamar la necesidad de un liderazgo del poder estatal («más Estado») ${ }^{38}$, y se conecta con la idea del Estado postergado y con los problemas que derivan de una ausencia de Estado no infrecuente en algunas democracias contemporáneas (experiencias latinoamericanas, democracias debilitadas, crisis económico-sistémicas en algunos regímenes políticos). Sin embargo, la ausencia de lealtad constitucional no supone siempre y en todo caso, la quiebra del propio sistema político, pues el entramado complejo de instancias de poder en la que vive la ciudadanía (la intervención — más o menos acentuada- de entes locales, regiones, Estado, organizaciones europeas e internacionales), sustentan de un modo u otro, de forma más o menos precaria además, la continuidad de dicha comunidad política. Ahora bien, en estos casos el mantenimiento de ese sistema político adolece de una falta de gobernabilidad, con una manifiesta carencia de lealtad constitucional que incluso lleva a la propia ciudadanía a adoptar en ocasiones el papel del Estado, gestionando u ofreciendo servicios que deberían ser satisfechos por el poder público. La apatía del Estado se ve compensada, en dichos casos, por el dinamismo ciudadano, o por la privatización de lo público.

La lealtad constitucional cumpliría, de este modo, dos fines básicos. De una parte, contribuye a reforzar el engarce y la conexión de las distintas instancias de poder que están al servicio de la ciudadanía y que ejercen sus propias competencias, pues la descentralización competencial está ligada a la profundización democrática. Pero de otra parte, reclama un cierto liderazgo del Estado o poder central perfectamente compatible con la descentralización citada. No hay, pues, compromisos constitucionales efectivos y reales cuando las instituciones y el poder caminan lejos de la Constitución misma, sin justicia social ni sentimiento constitucional, para lo que se requiere un adecuado conocimiento y una aplicabilidad plena de la Constitución misma. La lealtad responde, pues, al objetivo de lograr la identidad constitucional o el sentimiento sincero y crítico de identificación de la ciudadanía y los poderes con los principios constitucionales.

En el fondo, el principio de lealtad constitucional supone una llamada de atención respecto a una reformulación del concepto de soberanía que no se ha producido todavía. En efecto, la estabilidad de un sistema jurídico-político y de las personas que dependen del mismo ya no puede sustentarse solo sobre la idea de que existe un poder absoluto y perpetuo que reside en quien tiene el poder de decisión y la capacidad de dar leyes sin recibirlas (Bodino). Pero tampoco se consigue el equilibrio de un régimen político si se apela a la concepción de que cada persona es soberana y súbdita al tiempo al configurar la autoridad y formar parte de ella,

38 En tal sentido, no puede verse más que como una falta de lealtad la falta de previsión estatal en estos cuarenta años, abandonando sus competencias y haciendo dejación de las mismas en determinados territorios en determinadas ocasiones (Cataluña, País Vasco..., en el caso de la educación, etc.). Y por la otra parte, la utilización por parte de las minorías nacionalistas de la necesaria gobernabilidad, consiguiendo siempre cuotas de poder a cambio (negociación del cupo vasco, el 15\% o el 30\% del IRPF,...), al propio tiempo que exigían precisamente la ausencia del Estado de su territorio. 
pero también al comprometerse a obedecerla (Rousseau). La realidad es hoy mucho más compleja. La soberanía hoy, en consecuencia, necesita ser reformulada en términos de lealtad constitucional, sin que ello suponga inventar un término casi convirtiéndolo por ello mismo en un principio jurídico de rango quasi constitucional, por lo que se necesita una cierta cautela en la construcción de la lealtad constitucional. Cautela que la aporta, sin embargo, la propia trayectoria del principio, ya presente en ciertos ámbitos jurídicos.

\section{LEALTAD CONSTITUCIONAL Y ORDENAMIENTO JURÍDICO}

La constatación de una pluralidad jurídica evidente y la existencia de sistemas normativos separados obligados a encontrarse, con normas y políticas públicas que provienen de muy diversas instancias de poder, plantean la necesidad de generar una acomodación que tenga lugar sin dramatismos. Y es que si ya estaba en crisis el concepto de soberanía, ahora también puede estarlo el principio de unidad del ordenamiento, en una especie de tensión entre unidad y policentrismo político y jurídico. Si tratábamos de reformular la conceptualización del Estado mismo, igualmente se debe abordar la plenitud del ordenamiento jurídico a la luz de la lealtad ${ }^{39}$.

Al igual que se requería replantear el concepto de soberanía en términos de lealtad, lo mismo vale ahora para el derecho. Sin embargo, no vale cualquier tipo de unidad del ordenamiento, pues éste debe responder al objetivo de una mínima fundamentalidad en materia de derechos y, en concreto, a la garantía de la básica dignidad del ser humano. Un mínimo status para el ser humano que debe resultar, a su vez, compatible con las particularidades, con el pluralismo social, y con el ADN de una sociedad determinada. De este modo, el principio de lealtad constitucional se sitúa más allá de intereses concretos, sectoriales o privados, así como de la lógica de los mercados.

Esto supone entender que ya no hay political questions (actos políticos) en el sentido de que ya no hay aspecto de la vida cotidiana que no pueda ser enjuiciado en términos judiciales y que quede a la discrecionalidad particular y privada de quien decide, pues el derecho permea toda la realidad social. Cuestión distinta es hasta donde puede entrar un órgano judicial a valorar una decisión de otro órgano, pues la desaparición de ámbitos exentos de control judicial no impide que la justicia adopte al mismo tiempo una postura de deferencia o respeto hacia el legislador.

Por otro lado, e igualmente desde el principio de lealtad constitucional, lo anterior ha de hacerse compatible con la doctrina de las mayor questions (cuestiones importantes), según la cual habría determinados casos en los que, por su relevancia o

39 P. Carrozza, «El multilevel constitutionalism y el sistema de fuentes del derecho», Civitas. Revista Española de Derecho Europeo, n. ${ }^{\circ}$ 19, 2006. 
importancia social, los tribunales estarían obligados a fijar ciertos criterios, en garantía precisamente de la posición de la ciudadanía.

Se trata, como se observa, de buscar un delicado equilibrio que, en cualquier caso, siempre tiene un objetivo común: la garantía del núcleo indisponible del patrimonio constitucional a través de la búsqueda y alcance de la identidad constitucional. Como expresaría el profesor Sosa Wagner, la lealtad sería una suerte de salida o desahogo para la argumentación jurídica y la flexibilidad e integridad del ordenamiento cuando aquella se vuelve seca y demasiado rígida, representando «el confín que marca el territorio de las buenas maneras más allá del cual se abre otro en el que no es difícil que se extiendan la sombra del desconcierto y el germen del despropósito» ${ }^{40}$.

El principio de lealtad constitucional impone, pues, la reconstrucción del ordenamiento jurídico en los siguientes términos:

a) El derecho no es infalible ni inatacable. Es generado por los seres humanos y, en consecuencia, está sometido a los sentimientos y debilidades que caracterizan a aquellos. Así, se requiere, pues, destruir el mito de la certeza absoluta del derecho entendiendo que las normas pueden cambiarse siempre que ello tenga lugar a través de los mecanismos y procedimientos establecidos, y se valore al tiempo la pervivencia o no de aquellos aspectos que son fundamentales para la garantía de los derechos de la persona. Pero el hecho de que el derecho no sea infalible no implica su elaboración sin ciertas garantías. El respeto o la consideración del espíritu de las normas - que no supone otorgar a las mismas ninguna consideración vital-, debería obligar a que en el proceso de elaboración de aquellas el legislador atendiera efectivamente a los fines y objetivos que se pretenden, desechando prácticas legislativas que simplemente son una reacción, en un exceso de voluntarismo, a impulsos externos, con la nefasta consecuencia de que la no creencia en la norma misma la hace, paradójicamente, ineficaz e inaplicable en la práctica por el propio poder público que la elaboró.

El derecho responde, efectivamente, al ejercicio del poder y a su vez, ambos, a la realidad social misma. Y resulta evidente también, que existe una especie de difuminación en los contornos poder social/poder político. Por ello la norma de lealtad exige también que esta simbiosis, manteniendo sus ámbitos y espacios, sea considerada. De hecho, en la actualidad resultan sugerentes planteamientos de autores como Nye, que, desde la teoría del poder, efectivamente conciben éste como la capacidad para conseguir de los demás lo que uno quiere (objetivo que está también presente de forma genérica en el derecho), pero que sobre todo se centra en los contornos que pueda adoptar aquel, en sus efectos, aportando una importante tipología ${ }^{41}$. Este autor alude a un poder «duro» (hard power), el poder que da la fuerza física y la capacidad de coacción y amenaza, y junto al mismo la existencia de un poder «blando» (soft

\footnotetext{
40 F. Sosa Wagner, «La lealtad, gozne del Estado», Real, n. ${ }^{\circ}$ 288, 2002, pp. 107.

${ }^{41}$ J. NyE, The future of power, PublicAffairs, New York, 2011; y Soft Power: the means to success in world politics, PublicAffairs, New York, 2009.
} 
power), que sin recurrir a la represión y al dinero, usa la atracción, la persuasión y la influencia, la seducción: una especie de poder «amable». Y se refiere finalmente al poder del dinero, que este autor coloca en un tercer plano. De la combinación y uso adecuado de los tres, sostiene, deduciríamos el smart power o poder inteligente ${ }^{42}$. Es necesario tener en cuenta, nos advierte, que el poder duro puede superar al poder blando a corto plazo, pues éste último necesita tiempo y es difícil de construir y gestionar $^{43}$; y que el poder blando depende de lo que pase por la mente, por lo que requiere una estrategia más elaborada. Pero muchos sistemas políticos y muchos gobernantes son conscientes de que solo con la suma de los mismos conseguirán sus objetivos, serán comunidades políticas sólidas, mantendrán su hegemonía, y resultarán más atractivos (los casos de China o Estados Unidos en determinadas etapas de su historia hablan por sí solos). Las organizaciones, y no solo las instituciones políticas, ejercen además estos tipos de poderes cotidianamente (el caso del Isis, el terrorismo yihadista, es una buena muestra de uso inteligente del poder). El poder inteligente se ejerce, pues, cuando se tiene la capacidad de implementar una estrategia exitosa combinando ambos tipos de poder, pues si ello no ocurre, poder duro y poder blando se convertirán en antagónicos y acabarán confrontándose. De la combinación y el refuerzo mutuo resulta, en definitiva, un sistema político y social inteligente, pues cuando los gobiernos usan el poder duro mientras la sociedad ejerce el poder blando, y ello ocurre sin coordinación o de forma manipulada a la luz de intereses espúreos, puede producirse un choque que acabe por frustrar los compromisos que ambos pretenden. Es, sin lugar a dudas, complejo llegar a un punto de equilibrio. Para ello, sostiene este autor, se necesita franqueza y autocrítica, responsabilidad en resumidas cuentas. Pero el secreto está, además y en buena parte, en la utilización con cautela de las personas que integran una comunidad, pues el gobernante puede lograr un proyecto acabado si da rienda suelta, de forma liderada, a la sociedad civil. Se necesita, podríamos añadir, correspondencia con la norma de lealtad que debemos ser capaces de deducir de la Constitución misma.

Desde las anteriores aportaciones, la misma necesidad de responder a nuevos retos provenientes, en buena medida, del impulso centrípeto-centrífugo de instancias territoriales internas y supranacionales, pero también la complejidad social de nuestros días y tras cuarenta años de una Constitución que, no obstante, se revela aún joven, parecen aconsejar también un Derecho constitucional diverso, cooperativo, y basado en el diálogo y la negociación. Un Derecho constitucional que combine la rigidez con la flexibilidad, la fuerza con la persuasión, para llegar a un «derecho inteligente» (smart law).

42 Piénsese, a modo de ejemplo, en que determinadas conquistas que se alcanzaron durante la guerra fría con la caída del Muro de Berlín, fueron fruto de un poder blando, aunque aquel fuera derribado a martillazos.

43 Así se explica la consideración, por parte del Estado, de que los conflictos políticos únicamente se resuelven desde su consideración de poder político, caracterizado por el monopolio legitimo de la vis física. 
b) Relacionado con lo anterior, el derecho debería dejar de construirse sobre el modelo jurídico de los adversarios/antagónicos, lo cual supone evitar los compartimentos estancos pero también la concepción de la Constitución misma como mera vis fisica: la ley no se contrapone a la Constitución, ni el reglamento a la ley; y por las mismas razones, las normas no son patrimonio de unos partidos u otros, más si cabe cuando en nuestro ordenamiento las normas tienen, en no pocas ocasiones, rasgos pseudoconstitucionales por las materias que abordan. Las normas se complementan y quienes hacen las mismas confluyen en su elaboración. Y por la misma lógica, tampoco los Tratados son antagónicos a la Constitución, y de ahí que el debate control de convencionalidad/control de constitucionalidad no pueda llevarnos a planteamientos excluyentes, uno del otro ${ }^{44}$.

Tampoco la Constitución puede ser vista como un puro instrumento coercitivo —el más poderoso- del poder, pues «más bien se debería esperar de él que imponga, legal, social e institucionalmente, los fines y valores propios del constitucionalismo. Esta ha sido la vitola histórica del carácter troncal y propedéutico que lo distingue, al menos hasta hoy en que, debilitado el vínculo estatal del Derecho en el marco de un cambio radical y acelerado, se quedan a la intemperie numerosísimos y legítimos intereses que no encuentran tutela en un contexto caótico dónde sólo parece reinar la ley del más fuerte y la del beneficio» ${ }^{45}$. La Constitución tiene ante sí, y por ello, el gran reto de reagrupar todos estos intereses - seguro que diversamente razonables y muchas veces no coincidentes, según la opinión de las diversas partes que componen el pacto constitucional-, para ser capaz de integrarlos en un nuevo marco consensuado de libertad e igualdad. Porque precisamente las Constituciones no nacieron para épocas de felicidad sino para responder a las crisis, a la necesidad de alcanzar acuerdos, a imposiciones, al predominio de quienes se consideraban más fuertes o más legitimados que otros... Ningún sentido tiene hacer uso de la propia Constitución, bien como instrumento coercitivo mismo en su conjunto — cualquier medida de actuación al objeto de volver a una utópica e ideal libertad e igualdad desmembrada de los intereses de las personas que componen el acuerdo, pues en realidad está quebrándose ese pacto constitucional mismo-, bien a partir de los singulares instrumentos coercitivos que aquella contiene - los estados excepcionales, etc., pues estos no se accionan al margen y en contra del espíritu constitucional mismo-.

c) El Derecho constitucional no es un nuevo derecho natural neutro (un derecho «anterior» al Estado mismo), sino que se inscribe en una concreta realidad social y en un nuevo paradigma: la Constitución es fruto del consenso, de la construcción paulatina de valores comunes y de la voluntad de integración en un único proyecto, lo

${ }^{44}$ Sobre este complejo encaje, pero entendiendo el mismo como un todo, vid. L. JIMENA QuESADA, Jurisdicción nacional y control de convencionalidad: a propósito del diálogo judicial global y de la tutela multinivel de derechos, Aranzadi, Pamplona, 2013.

45 J.L. Cascajo Castro, «Constitución y Derecho Constitucional...» cit., p. 20. 
que implica una cierta cortesía jurídica. La búsqueda de una Constitución «identitaria» responde a la idea de eficacia. Y aquí de nuevo conviene interrogarse sobre el modelo democrático que la sostiene, pues coincidimos con Álvarez cuando afirmaba que «Seguramente, lo más compatible con la eficacia del ordenamiento jurídico, con la democracia y con la función de lealtad, es que ésta no excluya automáticamente ciertas expectativas, por su contenido valorativo, del procedimiento de la formación de la voluntad del Estado, sino tan sólo aquellas que se persigan a través de procedimientos antidemocráticos» ${ }^{46}$.

El Derecho constitucional es fruto del ejercicio del poder y de la sociedad en la que se integra, como suele expresarse a través de un clásico aforismo anglosajón: countries make Constitutions, Constitutions don't make countries. Esto significa que la neutralidad del derecho no es tal, lo que tiene una repercusión importante en el ámbito de la libertad y la igualdad. Y por ello, en este aspecto, la acción de la norma de lealtad se presenta especialmente intensa. De hecho, no ha sido extraño escuchar en todos estos años de vigencia de nuestra Constitución que la proclamación de la igualdad, cuya consecución repercutirá obviamente en la mayor extensión de la libertad para todos los sujetos políticos, no ha desarrollado todo su potencial normativo $^{47}$, principalmente o como punto de partida, por lo que se refiere a la igualdad de género, dado el carácter sexuado de la naturaleza humana y sin perjuicio de la desigualdad que acontece por otras causas. Pero en efecto, no se trata solo de poner de relieve un problema de alcance de determinadas conquistas sociales. En realidad es una cuestión que incide en el desarrollo y configuración de nuestro ordenamiento jurídico —y dentro de él, el orden constitucional—, como un instrumento mismo del poder y como un reflejo de la sociedad, poniendo de manifiesto la diversa consideración de los sujetos jurídico-políticos y los sesgos androcéntricos del sistema en su conjunto ${ }^{48}$. La realidad nos muestra las dificultades para la consecución de la coparticipación y la corresponsabilidad de los dos sexos, pues la distribución clásica de las funciones productivas y reproductivas de la sociedad (que bebe a su vez de la compartimentación espacio público/privado) sigue siendo nefasta, y por ello ni las instituciones públicas ni las privadas consiguen que el principio democrático se imponga de forma real y efectiva, haciéndose necesaria una lectura del derecho en este ámbito, desde la norma de lealtad ${ }^{49}$. Porque no se trata de igua-

46 L. Álvarez Álvarez, La lealtad constitucional... cit., pp. 66-67.

47 A. Figueruelo Burrieza, «Políticas Públicas previstas para la Igualdad real y efectiva», en A. Figueruelo Burrieza, M.L. Ibáñez Martínez, R.M. Merino Hernández, Igualdad ¿para qué? A propósito de la Ley Orgánica para la igualdad efectiva de mujeres y hombres, Comares, Granada, p. 194.

${ }^{48}$ El derecho es, nos indica Campos, una de las ciencias donde menos elaboración ha existido desde la Teoría feminista. Cfr. A. Campos Rubio, «Aportaciones iusfeministas a la revisión crítica del Derecho y a la experiencia jurídica», Mujeres y Derecho: pasado y presente. I Congreso multidisciplinar de la sección de Bizkaia de la Facultad de Derecho, 2008, pp. 167 ss.

49 J. Astola Madariaga, «Las mujeres y el Estado constitucional: un repaso al contenido de los grandes conceptos del Derecho Constitucional», en Mujeres y Derecho: pasado y presente. I Congreso multidisciplinar de la sección de Bizkaia de la Facultad de Derecho, 2008, p. 228. 
lar sin más, sino de disolver las desigualdades de género, para lo que se necesita un posicionamiento más rotundo y definitivo de la propia Constitución, al objeto de proclamar una igual dignidad para mujeres y hombres. Sin embargo, para ello se necesita algo más que una reforma constitucional, pues se requiere que el marco epistemológico que aporte el feminismo se integre en la misma Ciencia del derecho constitucional, pudiendo observarse, lamentablemente, que su receptividad ha sido escasa y sobre todo insuficiente ${ }^{50}$.

Nuestro problema sigue siendo la plenitud de la democracia material, lo que no podrá acontecer si mujeres y hombres no se erigen en auténticos sujetos de derecho, implicando abordar el pacto constitucional mismo para asegurar la efectividad de los derechos de las mujeres e introducir el ámbito doméstico en el espacio jurídico político $^{51}$. Ni el poder, ni el derecho, ni la sociedad pueden ignorar la subjetividad jurídica y política de sus individuos (pudiéndonos plantear cuantas veces en los discursos y en el imaginario colectivo se pone en cuestión la de las mujeres), ni tampoco con ello su mixitud sexual. Si las relaciones de poder siguen siendo asimétricas, el derecho tenderá a normalizar y legitimar lo existente, pues no podemos negar la fuerte tendencia que arrastra en nuestro ordenamiento la visibilización de unos sujetos hegemónicos y universales, abstractos. Por tales motivos, cuando alguna norma o política pública cuestione dicha hegemonía y hurgue en la realidad social, como hizo la LOI en 2007, deberemos preguntarnos hasta que punto hay cambios sociales que permitan una eficaz implementación de aquellas, o un cuerpo teórico importante que lo sustente.

En la base de estos desarrollos del Derecho constitucional desde la norma de lealtad se impone pensar en el absurdo de separar Derecho constitucional y Economía y Empresa, con el coste que actualmente existe para unirlos de una forma armónica. Se impone también reflexionar sobre el hecho de que el poder está en los grupos y en sus conexiones, y no en los seres humanos individualmente considerados aunque el Derecho constitucional sirva a éstos en cuanto tales. Y se necesita analizar el hecho de que no basta con que las personas estén o lleguen a un espacio, sino el valor que se les da con ello. En palabras de Celia Amorós, el espacio de los iguales, donde se reconoce, promociona y «considera» la individualidad, el espacio público androcentrista. Y el espacio de las idénticas, el privado que tira de ellas, de las mujeres, aunque estén presentes en el público; el privado como no esencial y donde «lo accidental» se convierte en esencia ${ }^{52}$.

${ }^{50}$ M.C. Torres DíAz, «Transferencia de conocimientos y feminismo jurídico: entre la teoría y la práctica constitucional», Revista General de Derecho Constitucional, n. ${ }^{\circ}$ 21, 2015.

51 M. Esquembre Cerdá, «Género y Ciudadanía, mujeres y Constitución», Feminismo/s, n. ${ }^{\circ} 8$, 2006, pp. 35 ss.; y «Las mujeres ante el cambio constitucional. Algunos apuntes desde una perspectiva feminista para una «reforma constituyente» de la Constitución Española», Atlánticas. Revista Internacional de Estudios Feministas, n. ${ }^{\circ}$ 1, 2016.

52 C. Amorós, «Espacio de los iguales, espacio de las idénticas. Notas sobre poder y principio de individuación», Arbor: ciencia, pensamiento y cultura, n. ${ }^{\circ}$ 503-504, 1987, pp. 113 ss. 
d) El derecho, y también el derecho constitucional, tienen un cierto carácter «difuso»: hay un pluralismo constitucional que debe obligatoriamente reconocerse. Pero que sea difuso no quiere decir que no tenga un eje ni un orden: la fundamentalidad constitucional se consolida y se define en último término desde el ordenamiento Estatal (en la Constitución) para luego volver a revertir en el orden supranacional del que al mismo tiempo aquel se alimenta. Se alude, así a la constitucionalización del orden internacional y no a la mera internacionalización del orden constitucional, pues los valores, principios y derechos deben ser asumidos por los Estados, sin que se trate de una mera yuxtaposición o superposición de ideas internacionales forzadas a ser recibidas por los Estados. Y esto es así porque los sujetos que conviven en un Estado no son universales, aunque los derechos o el fundamento que está en su base, la dignidad humana, lo sean. De nuevo, se trata de hacer compatible ambos extremos, en un complejo equilibrio. El orden internacional ayuda a construir el eje constitucional, pero este compromiso básico constitucional se diluye si no se hace sólido luego en los Estados mismos, de tal forma que la Constitución se convierte en el lugar último de encuentro. Un lugar de encuentro que puede ser desplazado si, pudiera darse el caso (y así ha sido en la historia de la humanidad), varios Estados se unen para formar un nuevo "patrimonio constitucional común», una nueva Constitución que los aglutine.

Ello nos lleva a un debate de fondo que incide en la propia Teoría de la Constitución y del Estado: ¿la Constitución es un simple elemento del Estado, o bien ha pasado esta en algún momento a adquirir sustantividad propia?. Tradicionalmente se consideró que el Estado no había sido más que el redimensionamiento de la necesidad de organización política a la que se vio abocada la sociedad misma. Y precisamente, la Constitución sirvió para abordar la organización del Estado, permitiéndole a éste actuar y funcionar de modo legítimo. No fue posible negar, por ello mismo, la asociación ya considerada natural entre Estado y Constitución, funcionando la segunda a modo de documento de identidad de la primera. Por tal razón, no se concebía, en principio y desde planteamientos tradicionales, que existiera un Estado sin Constitución, ni una Constitución sin Estado. Ahora bien, la cuestión clave —a la luz fundamentalmente de los cambios que han experimentado los Estados en las últimas décadas-, es efectivamente la del lugar que están llamadas a ocupar ambas teorías, una respecto a la otra, la Teoría del Estado y la Teoría de la Constitución.

Si mantenemos la primera tesis, la teoría de la Constitución tendría que subsumirse en la misma Teoría del Estado Si partimos del segundo posicionamiento, la Teoría de la Constitución se independiza de la Teoría del Estado. Creemos, en efecto, que existen importantes elementos de apoyo de esta tesis: la idea de Constitución como una decisión del poder constituyente — derivada de Siéyes—, o como la expresión del acto constitucional a que se refería Wise ${ }^{53}$. La Constitución puede suponer,

53 E.J. SiEYÈs, ¿Qué es el tercer Estado? Ensayo sobre los privilegios, Alianza, Madrid, 2008 (publicación original: 1789); J. WISE, A Vindication for the Government of the New England Churches, Kessinger Publishing, Whitefish, 2010 (publicación original: 1717). 
en efecto, un elemento clave de modulación de la Teoría del Estado, pues existen importantes consecuencias según se señale que la Constitución es un mero elemento del Estado (de su ordenamiento jurídico), o pueda sin embargo concluirse que el mismo Estado - o un nuevo concepto de éste- viene a ser creado por la propia Constitución. Un dilema que no siempre es fácilmente soluble, pues la Constitución puede crear el Estado o bien transformarlo radicalmente a través del ejercicio del poder constituyente o del poder constituyente constituido.

Ahora bien, aun con toda la transformación que ha experimentado nuestra Constitución en cuarenta años, no ha sido infrecuente que se minusvalorara todo el aparato conceptual que proviene de la Teoría del Estado — en su formulación originaria y para abordar los cambios acontecidos-, lo que puede deberse al complejo tránsito de nuestro anterior Derecho político hacia el Derecho constitucional, con esa tendencia a reenfocar la disciplina hacia su consideración como mera norma jurídica aislada de los elementos teórico-políticos citados. Una deriva que ha podido provocar ciertas carencias, pues será complejo entender la auténtica significación de la Constitución misma y su desarrollo democrático sin los elementos conformadores del Estado: conceptos como los de soberanía, nación, etc., aderezados por otros como los de democracia, división de poderes, formas de gobierno, etc. Estos conceptos básicos para el Derecho constitucional son, a nuestro juicio, propios de la disciplina, pues sin la Teoría del Estado reinterpretada a la luz de la teoría de la Constitución, resulta estéril abordar el fenómeno constitucional. Ahora bien, todo ello siempre que el uso de categorías dogmáticas, metodologías y saberes no se realice con contenidos propios de otras épocas pasadas. Por tales motivos, la propia teoría del Estado, lejos de aparcarse, necesita ser rearmada y «constitucionalizada» a partir de los grandes retos a los que se enfrenta el constitucionalismo actual, como la gobernanza multinivel y la globalización. Porque «debilitada la creencia de los juristas en la racionalidad de los códigos y en la soberanía de los Estados, el método jurídico no puede dar ya forma a lo que no tiene forma ni restituir la unidad allí dónde sólo hay indefinida casualidad de fines» ${ }^{54}$. Es decir, se trata de asumir que ciertas bases de la Teoría del Estado han de actualizarse reconfigurando o inventando nuevas categorías.

e) La calidad de las normas constituye un elemento clave para la reinterpretación del derecho en términos de lealtad, pues se trata, no sólo de mejorar la calidad de las normas desde su individualidad, sino de formular reglas y desarrollar prácticas que redunden en una mejora de la calidad del ordenamiento jurídico en su conjunto y en consonancia con la misma Constitución ${ }^{55}$. Ello implica, a grandes rasgos, la consideración de dos tipos de cuestiones:

${ }^{54}$ Cfr. J.L. Cascajo CaSTro, «Constitución y Derecho Constitucional...» cit., p. 21, con cita de Irti.

55 Vid. T. Vidal Marín, «Técnica legislativa, inserción de la norma en el ordenamiento jurídico y Tribunal Constitucional», Teoría y Realidad Constitucional, n. ${ }^{\circ}$ 31, 2013, p. 324. Asimismo, una obra clásica, E. García de EnTERría, Justicia y seguridad jurídica en un mundo de leyes desbocadas, Civitas, Madrid, 2006. 
— En la producción o elaboración de la norma. La realidad jurídica, que no es perfecta como se señaló, nos muestra una constante «motorización legislativa» contraria al principio de lealtad constitucional: se legisla a golpe de mayoría, abusando de instrumentos como los Decretos-leyes, con normas precipitadas, con leyes aprobadas de espaldas al orden supranacional y autonómico (en este último aspecto, todavía siendo necesario profundizar en las técnicas de cooperación Estado-Comunidades Autónomas respecto a temas europeos). Existe, en efecto, lo que se llama un cierto «nerviosismo legislativo», pues se atiende a demandas y presiones sociales, provenientes de determinados grupos de interés o poderes privados, sin atender de forma razonable a las causas que laten en el fondo de dichas normas y a las consecuencias que éstas generarán. De otra parte, se trata también de evitar que se ignoren las opiniones expresadas por otros órganos de colaboración normativa (Consejo de Estado, Consejo General del Poder Judicial, etc.), reforzando la capacidad argumentativa de las instituciones que participan así como la bidireccionalidad entre todos los implicados; y que se elaboren de la forma que corresponde todos aquellos informes dirigidos a medir el impacto que la norma tendrá sobre la sociedad (impacto de género, económico, etc.). Asimismo, no son leales las normas que hacen un excesivo uso de postulados promocionales y condicionales con expresiones como «se fomentará» o «se procurará», los cuales ponen en evidencia la «tibieza» del legislador con los compromisos sociales; ni tampoco cuando se introducen meros mandatos o deseos políticos en normas que no son las habilitadas para hacerlo — pues quien la elabora no tiene competencia para ello-, buscando presionar a quien efectivamente es titular de la competencia.

- En la evaluación y ejecución de las normas. Los riesgos y prácticas anteriores, alejadas del principio de lealtad constitucional, adolecen de un exceso de voluntarismo por parte de quien elabora la norma: se confía en que después el aplicador de la misma sabrá como ajustarla a la realidad social, sin haber analizado primero bien ésta. Ello va ligado a una exigencia de rigurosidad en las declaraciones políticas de los poderes públicos — pero también privados-: de un lado, la clase política pone en evidencia así la calidad democrática del sistema, al actuar conforme a la responsabilidad del cargo y demostrar el adecuado respeto y conocimiento del sistema jurídico-político; de otra parte, por la especial posición que le corresponde, los titulares del poder judicial deben encontrar en las sentencias - y no en otros medios de comunicación - el medio habitual para dirigirse a la ciudadanía; y finalmente, los poderes privados y la ciudadanía misma han de interiorizar el respeto al marco constitucional en tanto constituye un patrimonio propio, lo cual es, en buena parte, responsabilidad de los propios poderes públicos.

En resumidas cuentas, el ordenamiento jurídico parece desprenderse de la norma de lealtad que consideramos que está en su base cuando, en el desarrollo de la teoría 
de la Constitución en estos cuarenta años y como señala el profesor Garrorena, parece que se ha impuesto «un tremendo desenfoque que hoy padecemos al pensar que nuestra disciplina no consiste en que el Derecho Constitucional no sea el Derecho de la Constitución, sino que se le concibe como el Derecho de la Constitución «ya constituida» ${ }^{56}$. Lo cual puede desembocar en una especie de «desustancialización» del Derecho constitucional, pues las Constituciones dejan de versar sobre contenidos reales para dedicarse al funcionamiento aséptico de la maquinaria estatal ${ }^{57}$. Por ello, en resumidas cuentas, se trata de valorar si en la historia de la justicia constitucional y, en general del resto de poderes, éstos han contribuido a la dinamicidad creadora del Derecho constitucional, pues quien interpreta la Constitución necesariamente contribuye —o debería contribuir - a su transformación y, sobre todo, a «hacer pedagogía» de la misma y no renunciar a su «interpretación auténtica».

\section{LEALTAD CONSTITUCIONAL Y EJERCICIO DEL PODER}

El principio de lealtad constitucional se proyecta sobre la configuración, organización y colaboración de poderes, coadyuvando a la necesidad de un intenso diálogo entre los mismos ${ }^{58}$.

Eugenio d'Ors se pronunciaba sobre los términos en que ha de producirse un diálogo al decir que este tiene lugar cuando alguien de cualquier manera toma en cuenta el pensamiento ajeno, lo incorpora al suyo y establece con ello un contraste que lo lleva a manifestar la aceptación o la oposición a ese pensamiento ${ }^{59}$. Esto implica la superación de prácticas no poco frecuentes en los sistemas políticos, en los que tiene lugar un uso interesado del diálogo dirigido a legitimar lo ya previamente decidido en refuerzo, precisamente y de nuevo, de su autoridad.

La atención a los diversos tipos de diálogo (siguiendo el citado estudio de Walton) pone en evidencia de esta forma los modos en que puede fortalecerse la lealtad: entre otros, el de intereses o de negociación (para la resolución de conflictos, recibiendo y dando lo justo, articulando pactos o convenios inspirados en la razonabilidad), el deliberativo (ante un dilema, con una acción coordinada que permita la mejor decisión final), el de información (que implica un intercambio, un dar y un recibir), el institucional (y que se conecta con el buen gobierno, para converger, cada uno en su actividad y sin interferencias, pero fomentando al tiempo sinergias y eliminando obstáculos), o el participativo (que, implicando a la ciudadanía fun-

56 A. Garrorena Morales, «Cuatro tesis y un corolario sobre el Derecho Constitucional», Revista Española de Derecho Constitucional, n. ${ }^{\circ}$ 51, 1997, p. 41.

57 P. Lucas Verdú, »Reflexiones en torno y dentro del concepto de Constitución. La Constitución como norma y como integración política», Revista de Estudios Políticos, n. o 83, 1994, p. 22.

58 D. Walton, Fundamentals of Critical Argumentation, Cambridge University Press, New York, 2006.

59 E. D’Ors, De la amistad y del diálogo, Publicaciones de la Residencia de Estudiantes, Madrid, 1914. 
damentalmente lleva a que, en el desarrollo de una acción o una política, se conforme ésta eliminando resistencias y mejorándola de forma eficaz y con los mínimos efectos negativo). En cualquier caso, el diálogo estaría impregnado de la idea de bilateralidad.

De este modo, el principio de lealtad constitucional viene a imponer también aquí la reconstrucción del ejercicio del poder y en su proyección hacia la ciudadanía, en los siguientes términos:

a) La colaboración de poderes y con la ciudadanía en términos de lealtad constitucional. Los poderes se integran y equilibran en un sistema, pues no funcionan a través de la regla del monopolio ni del predominio de unos sobre otros: unos no pueden ser sustitutivos de otros. Todo ello teniendo en cuenta que, ante una crisis de gobierno o del propio sistema político, la posición de debilidad que tenga alguno o algunos de estos poderes tenderá a ser compensada por los otros, o incluso por los propios poderes privados. Es el caso, por citar algunos ejemplos, del denominado "gobierno de los jueces» en determinadas etapas de la historia de algunos países, o la tendencia de algunos poderes privados o de la propia ciudadanía a asumir funciones y competencias estatales. Se trataría, pues, de recuperar la idea de que las crisis son la condición normal de la democracia. Y, en consecuencia, donde se impone la plena normatividad del texto constitucional y no la adopción de medidas extraconstitucionales —o forzando en exceso la Constitución misma-.

De otro parte, esta reconstrucción de la separación de poderes obliga a desechar prácticas gubernamentales, parlamentarias y judiciales que parecen que tienden incluso a arraigarse, como el abuso de instrumentos poco colaborativos (Decretos-leyes o normas aprobadas fuera del Parlamento), la falta de aceptación de la legislación aprobada por la mayoría anterior (el caso de las diferentes leyes en materia educativa y el cambio de buena parte del ordenamiento en la Legislatura 2011-2015 son suficientemente ilustrativos), la ocupación de todas las instituciones del Estado por parte de la mayoría gubernamental (Tribunal Constitucional, Consejo General del Poder Judicial, Tribunal Supremo,...), la utilización de la mayoría gubernamental, especialmente en los supuestos de mayoría absoluta, de un auténtico rodillo sin respetar el significado de las minorías parlamentarias en un sistema parlamentario (práctica que no ha sido patrimonio exclusivo de un solo partido en cuarenta años), la tendencia de los poderes a actuar única y exclusivamente si hay una sanción ante una dejación de funciones (es complejo entender que ciertos poderes cumplirán con los principios constitucionales sólo por el mero hecho de que el Tribunal Constitucional pueda imponerles una multa, como prevé la reforma de la Ley Orgánica del Tribunal Constitucional mediante Ley Orgánica 15/2015, de 16 de octubre), a buscar el espíritu de la norma y no solo el cumplimiento de su tenor literal (a título de ejemplo, la distorsionada práctica de repartir las candidaturas a Magistrados del Tribunal Constitucional entre los partidos políticos cuando corresponde su nombramiento al Congreso y al Senado), a desarrollar algunos poderes 
indeseables excesos de jurisdicción (en tal sentido, también el Tribunal Constitucional es un órgano que debe colaborar con el resto de poderes del Estado pues, a título de ejemplo, la STC 31/2010, haciendo uso de una técnica interpretativa manipulativa, supuso una extralimitación innecesaria de sus funciones, con consecuencias políticas y jurídicas de sobra conocidas), o a interpretar de forma rigurosa los principios constitucionales y evitar petrificar incumplimientos de mandatos constitucionales (como ocurre con la reforma de la Ley Orgánica del Tribunal Constitucional mediante Ley Orgánica 8/2010, de 4 de noviembre, dirigida a facilitar la elección de los magistrados del Tribunal Constitucional en casos de cobertura de vacantes o renovación, al disponerse que el tiempo de retraso en la renovación por tercios de los magistrados se restará del mandato de los nuevos que fuesen designados, cuando sin embargo la Constitución es rotunda al establecer un mandato conciso para cada uno de ellos de 9 años).

Tras la idea de frenos y contrapesos que preside la relación entre poderes se encuentra, al tiempo, la relación misma poder-ciudadanía, que se ha construido a lo largo de la historia en una constante tensión por el debate sobre la conceptualización del sujeto político. En este sentido, la Constitución del 78 tuvo el firme propósito, en la línea de los textos constitucionales de la segunda postguerra, de hacer realidad la libre e igual dignidad de los diversos sujetos políticos y con el principio democrático que está en la base de la norma de lealtad. Sin embargo, casi cuarenta años de democracia han puesto en evidencia diversos aspectos deficitarios que llegan a mermar la noción misma de representación política ${ }^{60}$. En primer lugar, la necesidad de una regeneración democrática que pueda paliar la desafección ciudadana, que experimentó cierto cambio a raíz de los acontecimientos del 15-M en 2011. En segundo lugar, la corrección de la insuficiente presencia del sujeto político femenino, donde la reforma de la LOREG por la LO 3/2007 para la igualdad efectiva de mujeres y hombres no parece haber logrado afianzar el espíritu que la presidía y sobre todo, tampoco ha conseguido llegar a todas las instancias de poder, incluidos los partidos políticos. Y finalmente, la ficticia alusión a la representación territorial — que está en el fondo del debate sobre la reforma de Senado-, cuando el sujeto político por excelencia es la ciudadanía, pues un territorio no es per se sujeto político, y en tanto todo lo más cabe aludir a una representación ciudadana articulada, eso sí, sobre la base de un territorio determinado, o a la representación de determinados gobiernos territoriales.

La idea de colaboración ha pasado a sustentarse en una configuración proactiva del poder político, pues ahora se precisa que éste — interviniendo sobre una sociedad concreta y no sobre un ente «abstracto»- actúe sobre la misma, para reorientarla, configurarla, y promover los valores, principios y derechos constitucionales. Por ello

${ }^{60}$ El representante solo se representa a sí mismo, en una relación vacía de relación, en palabras del profesor Garrorena. Vid. A. Garrorena, Representación política y Constitución democrática, Civitas, Madrid, 1991. 
el Derecho constitucional de nuestros días ya no se limita a constatar la separación Sociedad-Estado, sino que debe verse obligado a reunificar ambos postulados, removiendo las bases sociales desde la lógica de una «gran política» de la que nos hablara Fioravanti $^{61}$. Y es que si ello no es así, corremos el riesgo de que la lealtad acabe concentrada en una mera obsesión por el carácter normativo de la Constitución, postergando el problema de sus fundamentos mismos. Como expresaba Cascajo, apoyándose en Müller «Se olvida así que toda norma, y más si cabe la norma constitucional, es algo más que una proposición lingüística estampada en un papel, que no puede agotar su aplicación en la interpretación o en el entendimiento de un texto ( $\mathrm{F}$. Müller). Se corre el riesgo pues de sustancializar los conceptos jurídicos y los componentes verbales de la norma, infiltrándose en la práctica del Derecho elementos irracionales de imposible comprobación ${ }^{62}$. Porque la Constitución no es sólo ley y jurisprudencia, siendo estos sólo, en realidad, instrumentos para hacer realidad aquella.

b) La potenciación de los instrumentos colaborativos. En particular, por un lado, la de aquellos que afectan a los tribunales y que les deberían conminar a evitar los retrasos injustificados en la emisión de resoluciones judiciales, a profundizar en técnicas de consulta de unos tribunales a otros, singularmente por lo que afecta a la relación entre tribunales españoles y supranacionales (cuestión prejudicial, etc.), a reforzar la capacidad argumentativa en las sentencias, la labor pedagógica de los Tribunales (cuando utilizan en las sentencia los obiter dicta — que no predeterminan el fallo o decisión final del caso, pero que constituyen un valioso complemento de aquel-), a considerar valiosos — por constructivos en cierta forma- los votos particulares de determinados jueces en las sentencias (que se apartan del fallo o del argumento principal de la sentencia), a usar el «diálogo silencioso» (cuando los Tribunales demuestran conocer la doctrina de otros tribunales), y sobre todo a utilizar el «diálogo explícito» (cuando los tribunales responden con fuerza argumentativa a las opiniones de otros).

c) La pluralidad de órganos de vigilancia constitucional. Se trata de evitar la idea de que existe un único órgano en posesión de la verdad jurídica (el Tribunal Constitucional), para afirmar que todos los operadores - aunque en distinta forma- contribuyen a hacer de la Constitución una realidad normativa efectiva. Y es que el derecho a la última palabra, que implica un liderazgo efectivo y responsable, no puede ser nunca el derecho a la totalidad de aquella, pues se traduce más bien en un diálogo colaborativo. Pero también se trata de evitar la proliferación innecesaria de entes auxiliares que, asumiendo tareas correspondientes a los clásicos poderes estatales en función de una supuesta garantía de la independencia en la gestión de la prestación correspondiente, o en aras al incremento de la eficacia en la misma, pueden

\footnotetext{
61 VV.AA., Poderes Públicos y Privados... cit.

${ }^{62}$ J.L. Cascajo Castro, «Constitución y Derecho Constitucional...» cit., pp. 18-19.
} 
ocultar en realidad una dejación de funciones por parte de quienes deben integrar el núcleo de poder, incidiendo en resumidas cuentas en la norma de lealtad ${ }^{63}$.

d) La reconsideración del papel de los partidos políticos. Ello obliga a repensar su naturaleza y sus funciones, en tanto canalizan la voluntad ciudadana, contribuyen al funcionamiento de las instituciones, y son elementos para la socialización política, pero sin que pueda considerarse que son órganos del Estado, pues se trata de meras asociaciones privadas de relevancia constitucional. En cualquier caso, tienen una posición privilegiada en el sistema que obliga a exigirles «sentido de Estado». Y en consonancia con ello, han de colaborar con las minorías, a pesar de la mayoría partidista, pero también con otros grupos sociales y económicos, evitando el puro electoralismo, sobre todo cuando están en juego proyectos o normas de relevancia constitucional y que afectan a la libertad y la igualdad de la ciudadanía ${ }^{64}$. Por ello mismo, se les ha de impedir de apropiación ideológica o partidista de principios o valores constitucionales que son comunes a la ciudadanía.

e) El compromiso de los lobbies, de los poderes privados y de la ciudadanía con el marco constitucional. En tanto agentes que colaboran y se integran en el marco socio-político, también los mismos son responsables de la garantía del bienestar ciudadano. Desde la norma de lealtad ello supone profundizar en los resortes necesarios para hacer realidad su compromiso con aquellos principios que parecía habían sido siempre responsabilidad de los poderes públicos. Es este, de hecho, uno de los retos de los sistemas políticos contemporáneos, pues no puede dejarse de lado la falta de cultura constitucional en nuestros poderes privados: por parte de algunas confesiones religiosas, al considerarse la empresa desde el exclusivo punto de vista del derecho de propiedad, en la actuación de algunos medios de comunicación que han olvidado en no pocas ocasiones que son responsables de una opinión pública libre, en determinadas actuaciones fraudulentas de los propios sindicatos, etc., entendiendo que la Constitución no les vincula y que pueden situarse al margen de la misma. Quizá un

${ }^{63}$ Piénsese en que, en el contexto del conflicto Estado central-Cataluña, como consecuencia de la votación de una Moción consecuencia de la interpelación urgente sobre el adoctrinamiento ideológico en los centros educativos en España presentada por el Grupo Parlamentario Ciudadanos y rechazada con el voto en contra del PSOE y la abstención del PP, aquel grupo presentó una Proposición de ley para la creación de una Agencia Independiente que asuma las funciones de la Alta Inspección Educativa, la Agencia de la Alta Inspección Educativa (Boletín Oficial de las Cortes Generales, Serie B: Proposiciones de ley, n. ${ }^{\circ}$ 168-1, 27 de octubre de 2017).

${ }^{64}$ En tal sentido, no podemos olvidar la tendencia de las minorías parlamentarias a emprender auténticas campañas electorales desde el comienzo de diversas legislaturas, mostrando un sistema de oposición también impropio de un modelo parlamentario. Y tampoco podemos olvidar la utilización, por parte de la minoría parlamentaria, de las instituciones constitucionales con una finalidad distinta de la inicialmente prevista: piénsese en el uso del recurso previo como un derecho de veto, o la presentación de mociones de censura (a los presidentes Suarez, González y Rajoy) sin la pretensión de lograr mayorías alternativas estables. 
incremento de la lealtad constitucional por parte de los poderes privados y de la sociedad civil redundará en su configuración como auténticos contrapoderes, uno de los déficits que también aqueja a nuestro sistema político.

La ciudadanía se encuentra en la tesitura de ir dejando de ocupar un papel meramente pasivo, sujeto por lo tanto a la fuerza y dominio del poder público, aunque los riesgos de manipulación son siempre evidentes. Recuérdese en tal sentido, el pensamiento de Spinoza, cuando nos señalaba la fragilidad de un poder «coactivo», en resumidas cuentas, pues admitía que «un hombre tiene a otro en su poder, cuando lo tiene encadenado, cuando le ha arrebatado sus armas y sus medios de defenderse o escapar, cuando le ha inspirado miedo o se lo ha ganado mediante un beneficio para que el beneficiado prefiera someterse a los deseos del benefactor antes que seguir los suyos propios, y regular su vida bajo el criterio de su benefactor antes que decidir por sí mismo», teniendo en cuenta que las personas tenderán a pensar que las cosas de la naturaleza ocurrirán, igual que ellas mismas, por razón de un fin. De esta forma, «quien tenga a un hombre en su poder por el primer o segundo modo (miedo), domina su cuerpo pero no su espíritu; mediante el tercero y el cuarto (beneficio) establece su derecho tanto sobre su espíritu cuanto sobre su cuerpo, durante tanto tiempo, al menos, cuanto duren el temor y la esperanza» ${ }^{65}$. A fin de cuentas la imposición de un poder, al margen de la norma de lealtad, implica construir las subjetividades de las personas mediante el planificado impacto del miedo y la esperanza, obviando que la debilidad de la sociedad y la manipulación por el poder, las evidentes asimetrías entre ambos, permanecerán.

Por los anteriores motivos, la norma de lealtad se conecta con la necesidad de construir o profundizar en una adecuada educación cívica, como espacio desde el cual fomentar una ciudadanía con una efectiva cultura política y democrática. Es en este ámbito, el de la educación, donde precisamente se requiere una intensa «democracia militante», como así evidencia por lo demás el art. $27 \mathrm{CE}$, y que exige una decidida apuesta por la construcción de un modelo educativo estable ${ }^{66}$. El conocido episodio de la asignatura «Educación para la Ciudadanía», en el que faltó una apuesta decidida y políticamente consensuada para llevar a cabo una auténtica educación en materia constitucional ${ }^{67}$; las discrepancias de modelos educativos en

65 B. SpINOZA, Ética demostrada según el orden geométrico, Tecnos, Madrid, 2007 (ed. original 16611675); y Tratado Político, Alianza, Madrid, 2004 (ed. original 1675-1677).

${ }_{66}$ Sobre la configuración de la educación en nuestro modelo constitucional, vid. A. FERnÁNDEZ Miranda-CAmpoamor, De la libertad de enseñanza al derecho a la educación: los derechos educativos en la Constitución Española, Centro de Estudios Ramón Areces, Madrid, 1988.

67 G. CÁmARA Villar, «El debate en España sobre la materia «Educación para la ciudadanía y los derechos humanos» ante su proyectada supresión y cambio», en VV.AA., Constitución y Democracia ayer y hoy. Libro homenaje a Antonio Torres del Moral, Vol. 2, Universitas, Madrid, 2002, pp. 2401 ss. Asimismo, desde una perspectiva más amplia, M. Monzón Julve, Tesis Doctoral Educación en el ordenamiento constitucional: una apuesta renovada de democracia militante (Educación para la ciudadanía y desarrollo de los valores constitucionales, Universitat de València, 2015. Disponible en http://roderic.uv.es/bitstream/ handle/10550/57967/Tesis.Doctoral.Maria.Monzon.VERSION.DEFINITIVA.para.imprimir.pdf?sequence $=1$ (acceso: 25-9-2017). 
las diversas Comunidades Autónomas —en ocasiones ligados además a los elementos lingüísticos—- donde ha venido a señalarse con razones más que evidentes que el Estado central debía haber llevado a cabo un ejercicio más decidido de sus competencias ${ }^{68}$; la multiplicidad de normas educativas en casi cuarenta años de democracia, que impiden desarrollar un modelo educativo coherente a largo plazo; y, en resumen, los conflictos sociales generados en este ámbito como consecuencia de lo anteriormente expuesto, son una buena muestra de la necesidad de retomar la idea de un Pacto por la Educación que habría de ir ligada a la elaboración de una Ley de Educación que efectivamente fuera fruto de un consenso constitucional. La democracia militante en materia de educación exige, en consecuencia, un activismo presidido por la idea de un proyecto de futuro dialogado y de colaboración interterritorial y con los agentes sociales afectados.

La consideración de la educación como un ámbito privilegiado de la norma de lealtad y, con ello, la constitucionalización del espacio privado, no supone sino la profundización en el concepto de «Constitución identitaria» o, lo que es lo mismo, aquella que es capaz de generar una adhesión cívica a la multiplicidad de ordenamientos jurídicos e instituciones que se integran en un único proyecto constitucional $^{69}$. En una especie de auténtico «derecho común» para el ordenamiento jurídico y político, que ejercería una función similar a la que el derecho privado ha venido cumpliendo pues, desde sus orígenes en Roma, era donde efectivamente la ciudadanía podía defenderse a sí misma; y ello hasta la llegada del constitucionalismo contemporáneo en el que se inicia la paulatina, lenta e inacabada sustitución de uno —el Derecho privado— por otro —el Derecho constitucional-.

La adhesión a la Constitución no ha podido sustentarse sobre las ideas de consenso y pacto generadas hace ya casi cuarenta años, y que ahora debe intentar retomar una lealtad colectiva — no esencialista ni idealizada, sino integrada por seres individuales_- capaz de aunar de forma libremente razonada pluralismo y unidad. Porque la Constitución es al tiempo lo común y lo individual. Lo común, porque responde a la idea de pacto constitucional, de consenso y de proyecto en el que

68 En tal sentido, M. Aragón Reyes, «Las competencias en materia de educación en las Comunidades Autónomas», Revista Española de Derecho Constitucional, n. ${ }^{3} 33$, 2013, pp. 191 ss.; F.J. DíEZ Revorio, "Comunidades Autónomas y Educación», Revista Jurídica de Castilla-La Mancha, n. ${ }^{\circ} 32$, 2002, pp. 85 ss.

${ }^{69}$ Tal planteamiento posee raíces profundas en el pensamiento político, desde Roma, pasando por el humanismo renacentista, y hasta llegar a los planteamientos de Kant, Dahrendorf, Arendt o Habermas. Podríamos pensar si los avatares históricos de nuestro Derecho constitucional y, por ende, de su objeto, están mostrándonos que nuestra disciplina todavía paga la falta de continuidad y tradición que ha tenido. Una apreciación que manifestaba Böckenförde desde la doctrina alemana, cuando se lamentaba de la imposibilidad de recurrir a un Derecho constitucional general —-más allá de la Constitución escrita- del Estado Social y Democrático de Derecho, si lo comparamos con lo acontecido en el Derecho administrativo. E.W. Böckenförde, Stato, Costituzione, Democrazia. Studi di Teoría della Costituzione e di Diritto costituzionale, Giuffrè, Milano, 2006. 
integrar una diversidad; y lo individual, porque se trata de conseguir la extensión de la forma más igualitaria posible de los espacios de libertad que nos corresponde, procurando hacer realidad la dignidad humana.

La norma de lealtad evidencia, pues, que los resortes incontrolados del poder más allá del proyecto común que pertenece a las personas que integran la comunidad en la que aquel ejerce sus funciones, pueden obedecer a las mismas premisas en un régimen democrático que no democrático: el miedo y el beneficio. Sin embargo, solo la norma de lealtad viene a corregir estos vicios que se dan incluso en las democracias, pudiendo considerarse que aquella es entonces innata al principio democrático mismo.

\section{LEALTAD CONSTITUCIONAL EN UN SISTEMA MULTINIVEL}

El principio de lealtad constitucional es necesario para la plena normatividad de la Constitución, pero también para hacer factible y coherente la realidad multinivel en la que nos encontramos y que obliga a armar bien, en incluso como paso previo, jurídica y políticamente la constitucionalización del orden interno y de sus operadores políticos, evitando discursos y posturas aparentes y vacías de contenido. Se trata, en efecto, de superar la visión estatocéntrica propia de los S. XIX y XX dando lugar a un nuevo liderazgo del eje estatal, dada la evidente reducción de los ámbitos políticos estatales, y para dejar de vivir de espaldas al constitucionalismo multinivel, pues posiblemente si algún poder omite esta realidad otro también lo haga, minando con ello la colaboración. Por ello se requiere una búsqueda constante del reequilibrio entre las diversas instancias, que debe pasar por una reconstitucionalización profunda del eje estatal, y también por una colaboración intensa que no por ello deja de ser compleja- con los poderes internacionales y con los poderes privados y contrapoderes del sistema (universidades, empresas, colegios profesionales, sociedad misma).

No obstante, hemos constatado en todos estos años que la expresión «constitucionalismo multinivel» despierta pasiones, pero también incertidumbres y cautelas. Esto es ciertamente comprensible, pues al fin y al cabo, si con la venida de la democracia en el año 78 ya nos estaba resultando complicado adaptarnos a un Derecho constitucional por carecer de un cuerpo doctrinal de referencia - lo que no elimina la existencia de muy importantes aportaciones teóricas desde otras metodologías-, no menos complicado iba a ser que, casi al mismo tiempo, nos enfrentáramos paralelamente a una compleja realidad supranacional emergente que podía desbordar todas las expectativas.

No obstante, la realidad evidente de un Derecho constitucional europeo y de una gobernanza multinivel suponía, de una parte, un constitucionalismo dinámico, plural, de soberanía compartida, con un demos europeo, una coordinación de poderes, y un liderazgo que de facto es difuso y que jurídicamente todavía anda necesitado de unas 
bases más sólidas ${ }^{70}$. Pero también ha tenido un impacto sobre la comprensión de la Constitución misma de un modo más interdisciplinar y abierto internacionalmente a los avances metodológicos de la doctrina de otros países, cuya madurez constitucional e institucional — por la realidad o la necesidad política - resultaba en algunos aspectos o en algunos momentos, más evidente ${ }^{71}$.

En cierta forma, parece, pues, que nos hemos encontrado ante una especie de «Constitución sin Estado», de «Estado sin Constitución» o de ambas cosas al tiempo. Una especie de diversos círculos constitucionales con distintas dimensiones, ordenados por niveles o, más acertadamente, en una especie de gobernanza basada en una poliarquía deliberativa «en red», y destinados a confluir de forma dinámica a través de interacciones recíprocas. Zagrebelsky nos exponía, en tal sentido, cómo autores como Pernice e Mayer imaginan, no tanto una federación de Estados o un Estado Federal, sino una especie de «federación de constituciones» (Verfassungsverbund) que legitimarían el gobierno a diversos niveles y la participación de los particulares en aquél ${ }^{72}$.

Pero la idea anterior también tiene su parte compleja y problemática: la idea paralela que genera la gobernanza, de un «estatismo sin Estado», o una separación tan manifiesta entre poder (o capacidad de conseguir que se hagan las cosas) y política (o capacidad para decidir qué cosas deben o deberían hacerse), o entre toma de decisiones (quien efectivamente decide) y responsabilidad (a quien se le pide cuentas), que explicaría las razones por la que los Estados son incapaces de gestionar apropiadamente los intereses de sus comunidades. La fractura entre lo local y lo global (glocalización vs. globalización) estaría imposibilitando que las necesidades cotidianas se vean satisfechas por un decisionismo supranacional al que aquellas le resultan demasiado lejanas. Y al final, la ciudadanía corriendo el riesgo de cierta manipulación, o preocupada de procurarse ella misma su bienestar social.

En cualquier caso, estamos ya ante la «parcial» — si se quiere-construcción de un Derecho constitucional común europeo. Parcial porque, por el momento, se trata de compartir ciertos contenidos nucleares de los valores y principios constitucionales; porque se trata de ponerlo en común y buscar la coordinación para

70 I. PERnICE, «El constitucionalismo multinivel en la Unión Europea», ReDCE, n. ${ }^{\circ}$ 17, 2012.

71 Reflexiona sobre la idea de si incluso no habría llegado el momento de configurar un Derecho Constitucional Europeo como disciplina autónoma (cuya opción más neutra podría ser la de situarla entre el Derecho constitucional clásico y el Derecho comunitario). S. Pinon, «El Derecho Constitucional Europeo: ¿una disciplina autónoma?», ReDCE, n. ${ }^{\circ} 13,2010$, pp. 267 ss.

72 Traduciendo desde el italiano, expresa Zagrebelsky que cada persona pertenece a varios círculos constitucionales, es portadora de «ciudadanías» múltiples y en cada una encuentra el lugar para la expansión de su propia personalidad y de su propia libertad; y ello aunque esto puede dar lugar a una dificultad derivada de la simultánea vigencia de más de un ordenamiento jurídico en el mismo ámbito, y no sólo en el caso de divergencias: la erosión del consenso que debe unir a los particulares en sus ámbitos de pertenencia. Vid. G. Zagrebelsky, «Introduzione», a la obra G. Zagrebelsky (a cura di), Diritti e Costituzione nell'Unione Europea, Ed. Laterza, Bari, 2003, pp. VII y XII. 
construir nuevos espacios y metas que redunden en dichos objetivos de libertad e igualdad; y porque se trata de lograrlo mediante la regla de la subsidiariedad o, lo que es lo mismo, de forma dialogada, y no tanto depositando en el poder más bajo la capacidad de decisión (como se pretende con una definición, a nuestro juicio errónea, de la mencionada nota de subsidiariedad).

El recurso al diálogo y al encaje multinivel no es, por estas razones, un mero concepto vacío: responde a un principio constitucional (la lealtad constitucional) y a un nuevo paradigma (el de un constitucionalismo plural y difuso). Un diálogo que debe huir de planteamientos antagónicos y adversarios, e incluso de posibles discursos basados en la «complementariedad»: porque una instancia o un poder no complementa a otro para ganar peso uno y perderlo el otro, sino que se pretende que implique la conformación de algo nuevo y original, que sin embargo no supone elaborar a partir de la nada

De otra parte, si algún desarrollo ha tenido el principio de lealtad en relación con la colaboración de poderes en sentido horizontal es en el ámbito del modelo territorial de Estado. Se ha señalado del principio de lealtad federal, de amplia trayectoria en el sistema alemán y luego extendido a otros países como Bélgica y Suiza, que el mismo impone a la federación y los entes federados un deber de comportamiento favorable a la Federación, debiendo a tal efecto protegerse los intereses comunes pero también los de sus Estados miembros. Dicho deber se bifurca en dos dimensiones: una negativa, o de un deber de abstención y no intervención en los ámbitos competenciales del otro ente; y otra positiva, de actuación para asegurar los fines del Estado ${ }^{73}$. Ahora bien, no es éste el único instrumento destinado a articular el correcto ejercicio de las funciones que corresponden a los distintos entes en un Estado descentralizado, pues es sabido, en tal sentido, que el modelo norteamericano se basa en el principio de cooperación intergubernamental.

En nuestro país se ha debatido durante años sobre la vigencia de la lealtad federal, argumentándose en contra, sustancialmente y como recoge la profesora Biglino ${ }^{74}$, que nuestro Estado de las autonomías no se sustenta sobre la noción de pacto federal y que cabe, todo lo más, la aplicación de una lealtad constitucional entendida como ejercicio no abusivo de las propias competencias (y desglosada en diversos deberes como el de información, auxilio mutuo, etc. SSTC 66/1983 y

73 Si bien el deber positivo fue regulado en la Ley 30/1992, y ahora en la Ley 39/2015, resulta más compleja la delimitación y concreción del negativo. Por lo demás, del principio de lealtad se desprenderían, en cualquier caso, un deber de reciprocidad (no se puede alegar el incumplimiento de lo ajeno para justificar el incumplimiento de lo propio), cooperación obligatoria (pues cuando hay concurrencia no basta la buena voluntad), e indisponibilidad de las competencias (que no pueden condicionarse mediante convenios o subvenciones). Cfr. las intervenciones de Biglino y Enoch en la crónica de A. GonZÁlez Alonso, «La lealtad constitucional. La Constitución como orden de valores o como procedimiento»... cit. Asimismo, P. Biglino, «La lealtad constitucional en el Estado de las Autonomías», Revista Jurídica de Castilla y León, 2004. Sobre el modelo alemán, J. LAso PÉREZ, «La lealtad federal en el sistema constitucional alemán», Cuadernos de Derecho Público, n. ${ }^{\circ}$ 9, 2000, pp. 47 ss.

${ }^{7}$ P. BigLino, «La lealtad constitucional...» cit., p. 341. 
18/1992). Efectivamente, dicha regla del ejercicio no abusivo de las propias competencias sería una solución aceptable si el reparto de competencias constitucionalmente determinado no se articulara sobre fines y funciones, y además no permaneciera constantemente abierto, ya que en estos casos, por definición, como ocurre en nuestro sistema, los conflictos territoriales están servidos. La configuración de las competencias como absolutamente indeclinables generaría, en efecto, un permanente conflicto que solo puede ser reparado a través de un intenso sistema cooperativo que en nuestro país no existe o cuanto menos es significativamente deficiente. Y esto ha hecho que, en consecuencia, la lealtad constitucional-territorial tal y como pretende ser diseñada por parte del Tribunal Constitucional, resulte completamente inoperativa. Así, aunque el reparto de competencias nunca puede ser estático sino dinámico, sí debe ser lo suficientemente garantista.

El principio de lealtad federal se incardina de este modo en una más genérica norma de lealtad constitucional. Se pretende con el principio de lealtad, evitar la imposición de las respectivas competencias propias, pero también se trata de que la «autocontención» individual que corresponde a cada ente - y que ha sido configurada desde la doctrina constitucional—, se vea acompañada de los mecanismos precisos para un ejercicio de las respectivas potestades en diálogo con los otros entes implicados. Como recuerda Biglino, no se trata de ejercer las competencias contra o a costa del otro ente, sino con el mismo. Con ello, además, se produce un mejor - $-\mathrm{y}$ necesario- encaje de la política con el derecho, evitando la constante judicialización de los conflictos territoriales pero también la radicalización o magnificación de ciertos conceptos como el de «interés general» o el de «unidad constitucional», que no tienen sentido sino desde la norma de lealtad. Y ello sin que pueda desecharse, y aquí la bibliografía en estos cuarenta años es ingente, el refuerzo de instrumentos cooperativos - respecto a los cuales la Ley 40/2015, en sus arts. 143 y siguientes, no parece aportar novedades significativas-, y la clásica cuestión de la reforma del Senado.

Los riesgos de la norma de lealtad que hemos anunciado en otras partes de este estudio y que se traducían en una huida de la misma hacia el terreno de la política abandonando el terreno del derecho, o incluso hacia posicionamientos metapositivos, perdiendo a tal efecto sustantividad jurídica, también fueron puestos de manifiesto en la misma doctrina alemana a raíz del Bundestreue, que como dijimos goza de una amplia trayectoria en este país. El debate generado oscilaba, pues, entre quienes convertían el principio de lealtad federal en un elemento más que central del federalismo alemán, y quienes lo observaban como un mito configurado de forma desmedida. Pero en cualquier caso, sirvió para conformar toda una serie de derechos y deberes para los diversos entes territoriales y enlazar una articulación territorial cooperativa — de la que se afirma que respondió en sus inicios a planteamientos políticos más que a un sólido deber jurídico previo- con la consolidación paulatina de un concepto jurídico de lealtad ${ }^{75}$. Así pues, llegando a una configuración que sitúa la lealtad en algo

75 J. LAso PÉrez, «La lealtad federal en el sistema...» cit., pp. 103-105. 
más que un mero recurso retórico carente de contenido alguno, o una simple arma arrojadiza frente al adversario ${ }^{76}$.

En cualquier caso, aunque resulte una obviedad señalarlo, la lealtad ha de tener lugar por ambas partes pues, a pesar de la cierta labor de «tutela» que ejerce el Estado central y que ciertamente implica un cierto plus de responsabilidad, también las Comunidades Autónomas son Estado.

En particular, también los déficits del Estado de las Autonomías durante estos años de democracia desde la aprobación de la Constitución con una insuficiente implementación del principio de lealtad federal, ha tenido sus consecuencias si conectamos el nivel infraestatal con el supraestatal, mostrando la necesidad de seguir profundizando en las técnicas articuladoras de los diversos niveles de gobierno. Como es conocido, la Unión Europea ha sido diseñada a través de la idea del Estado central como único interlocutor válido. Y aunque es cierto que se han previsto algunos instrumentos de participación de las Comunidades Autónomas en asuntos europeos (Comité de las Regiones, representación de las Regiones en Bruselas, mecanismo de alerta temprana), continua siendo deficitario el sistema institucional y procedimental interno para su encaje, a diferencia de lo que ha sucedido en otros Estados ${ }^{77}$.

También en el ámbito europeo, de otro lado, tiene su vigencia el principio de «lealtad europea» (o principio de cooperación leal), que se traduce como cooperación sincera en el cumplimiento de las obligaciones europeas, y cuyo objetivo precisamente es el encaje de los diversos niveles que operan en la gobernanza europea. El art. 4.3 TUE se refiere a ello cuando dispone que «Conforme al principio de cooperación leal, la Unión y los Estados miembros se respetarán y asistirán mutuamente en el cumplimiento de las misiones derivadas de los Tratados. Los Estados miembros adoptarán todas las medidas generales o particulares apropiadas para asegurar el cumplimiento de las obligaciones derivadas de los Tratados o resultantes de los actos de las instituciones de la Unión. Los Estados miembros ayudarán a la Unión en el cumplimiento de su misión y se abstendrán de toda medida que pueda poner en peligro la consecución de los objetivos de la Unión».

Se trata de un principio marco, de larga trayectoria y de inspiración alemana, que se proyecta en diversas partes del Tratado, pero que sobre todo ha sido usado profusamente por el Tribunal de Justicia de la Unión Europea con el objetivo de garantizar la efectiva aplicación del derecho europeo. De modo similar al principio de lealtad federal, la lealtad europea conllevaría igualmente una doble obligación: negativa, de abstenerse los Estados de adoptar medidas que puedan poner en peligro

76 G. Cámara Villar, «El principio de colaboración entre el Estado y las Comunidades Autónomas», Revista de Derecho Constitucional Europeo, n. ${ }^{\circ}$ 1, 2004, pp. 197 ss.

77 E. Albertí Rovira, L.I. Ortega Álvarez, J.A. Montilla Martos, Las Comunidades Autónomas en la Unión Europea, Centro de Estudios Políticos y Constitucionales, Madrid, 2005; S. MuÑOZ Machado (Coord.), Las Comunidades Autónomas y la Unión Europea, Academia Europea de Ciencias y Artes, Madrid, 2013. 
los objetivos del Tratado; y una doble positiva que supone, de una parte, la adopción de medidas necesarias para asegurar las obligaciones derivadas del Tratado o que resultan de la actividad de las instituciones europeas y, de otro lado, la obligación de garantizar a la unión el cumplimiento de su misión. Pero quizá, desde una perspectiva más genérica, desde una perspectiva más genérica y tal y como requiere la norma de lealtad, destaca que el Tribunal de Luxemburgo haya hecho uso de este principio argumentando en torno a la eficacia y conformación del mismo proyecto que está en la base de la Unión y que es construido constantemente, en buena parte, gracias a la labor pretoriana del mismo Tribunal. Por ello, esta institución europea pasó, de una fase en la que esta norma de lealtad constituía una genérica obligación general de buena fe, inspiradora para los Estados, a otra en la que ha configurado el art. 10 TCE como un principio susceptible de generar una infracción autónoma de la que derivaría un evidente incumplimiento del derecho de la Unión ${ }^{78}$.

El engarce multinivel entre entidades territoriales diversas se lleva hasta sus últimas consecuencias cuando la propia Unión ha sostenido que constituye una lesión del principio de lealtad, tanto el movimiento de entes regionales que pretendan llevar a cabo una declaración unilateral de independencia, como incluso el de aquellos Estados miembros que permiten dichas secesiones de acuerdo, ya no solo a sus normas constitucionales, sino también sin considerar los intereses y las propias normas de la Unión Europea $^{79}$. Sin dejar de admitirse que los proyectos nacionales no son, en virtud de una voluntad pseudodivina, indestructibles, y que responden en consecuencia a la necesidad de encajar el binomio constitución-democracia, lo cierto es que la Unión pretende enfatizar el mensaje - a través de la proclamación de un principio que se deduce directamente del derecho originario-, de que la construcción de un gran proyecto constitucional europeo implica per se la voluntad y esfuerzo por parte de quienes lo conforman, para integrar a las diversas colectividades e intereses que confluyen en su sistema político. Si nos encontramos en esta lógica, y teniendo en cuenta en la actualidad el conflicto territorial que se vive entre el Estado central y Cataluña, es legítimo y casi obligado un cierto protagonismo y responsabilidad de la propia Unión —que no necesariamente «mediación»- en los posibles conflictos territoriales que puedan sucederse. Con ello no se trata de hacer intervenir a un sujeto extraño en una cuestión interna, sino de asumir que el constitucionalismo multinivel conlleva una difusión de responsabilidades que obliga a la construcción de soluciones comunes.

Resulta obvio, a la luz de consideraciones anteriores, que los propios poderes que interactúan en una gobernanza multinivel están viendo mutada en cierta forma su

${ }^{78}$ Vid. J. Laso Pérez, La cooperación leal en el ordenamiento comunitario, Colex, Madrid, 2000; M.D. Blázquez Peinado, El procedimiento contra los Estados miembros por incumplimiento del derecho comunitario, Universitat Jaume I, Castellón, 2000.

79 Vid. J. De Miguel Bárcena, «La cuestión de la secesión en la Unión Europea: una visión constitucional», Revista de Estudios Políticos, n. ${ }^{\circ} 165,2014$, pp. 243 ss. 
propia naturaleza o acrecentada su complejidad. Los Tribunales no son órganos limitados a resolver litigios y conflictos; el poder legislativo no es el productor privilegiado de la norma; y el poder ejecutivo no es aquel que responde a la pasión de la dirección política. Pero asimismo, tampoco la ciudadanía y los poderes privados viven - o no deberían vivir- ya en sus propios intereses, ajenos a los compromisos constitucionales. Pero esta reordenación del poder, de la sociedad y de las normas no resulta nada fácil, motivo por el cual la llamada al principio de lealtad constitucional se hace más necesaria. En efecto, hemos llegado a una etapa en que, señala Bauman, el poder parece difuminado y la sociedad se presenta de una forma líquida y descompuesta en cierta forma, viendo reducidos sus espacios ${ }^{80}$, o en lo que la profesora Ferraresse denomina la incompiutezza del potere ${ }^{81}$. Porque no siempre quien tiene capacidad de hacer cosas — y terminarlas — es quien tiene la capacidad para decir qué puede o no puede hacerse en tanto su resolución corresponde a otros niveles. Porque es más frecuente de lo que parece que quien tiene poder no tenga responsabilidad y quien tiene la responsabilidad no tenga el poder efectivo ${ }^{82}$. La lealtad expresada a través del conocimiento que unas instancias tienen de otras, y del que todos los operadores tendrán del ordenamiento y de sus principios básicos, se revelará clave para el correcto y coherente funcionamiento del sistema.

De este modo, se llega a otro de los condicionantes básicos: el fomento de una cultura del pacto, del compromiso, en clave bidireccional, lo que requerirá al mismo tiempo que cuando se intenten adaptar instituciones o conceptos a la realidad social ello se haga sin una mera transposición automática, sino con análisis serios y rigurosos.

80 «Tengo la impresión —decía Bauman- de que los Gobiernos de los Estados no «eligen» ni «deciden» nada, salvo cuando se ven forzados a hacerlo (o, cuando menos, fingen que son obligados a hacerlo) por otros Gobiernos más potentes de países con mayores recursos, o por unas fuerzas amorfas y anónimas no registradas en la constitución de ningún Estado y que reciben denominaciones variopintas como «realidad del momento», «mercados mundiales», «decisiones de los inversores», o simplemente «NHA» (no hay alternativa)». Z. BAuman, C. Bordoni, Estado de crisis, cit., pp. 45 ss.

81 M.R. Ferrarese, «Governance. Sugli effetti politici e giuridici...» cit., p. 163.

82 El estudio de LEÓn-ALFOnSo y FERrín PEREIRA pone en evidencia que el proceso de aprendizaje de la ciudadanía sobre las diversas competencias de las administraciones se produce de manera selectiva, por lo que aquella aprende y mejora su conocimiento sobre lo que le interesa y cuando dispone de cierto nivel de conocimiento previo o capacidad para integrar la nueva información. Por otro lado, las personas que se sitúan en la izquierda del espacio ideológico señalan al Gobierno autonómico como responsable en un mayor número de políticas que quienes están en el centro, mientras quien se ubica en posiciones ideológicas de derecha le dan a la administración autonómica un menor número de competencias. Asimismo, la atribución de competencias al gobierno central disminuye entre quienes valoran muy bien las políticas y se sienten nacionalistas, mientras que aumentan entre las situadas en la derecha de la escala ideológica. Con ello quiere decirse que la ciudadanía atribuirá la competencia al nivel de gobierno con el que más tienda a identificarse. Cfr. el trabajo de S. León-Alfonso, M. Ferrín PereiRA, «La atribución de responsabilidades sobre las políticas públicas en un sistema de gobierno multinivel», Administración E Ciudadanía, n. ${ }^{\circ}$ 1, vol. 2, 2007, pp. 50 ss. 
La lealtad constitucional implica, en resumidas cuentas, un encaje normativo y de poderes, pues el ejercicio de los mismos a través de la emanación de normas y políticas públicas es un instrumento para la resolución de los conflictos y la procura del bienestar ciudadano. Las democracias actuales no pueden sino ser democracias colaborativas y cooperativas, basadas en el principio de confianza.

\section{CONCLUSIONES}

El balance de una joven democracia que apenas cumple cuarenta años nos lleva - quizá como en tantas otras cuestiones-, a reivindicar la necesidad de mayores esfuerzos por la doctrina y por parte de los poderes públicos (y privados), en torno a una cultura de la lealtad constitucional. Somos conscientes de que la configuración jurídico-política de este principio presenta todavía contornos imprecisos y ambiguos, y también constatamos que las aportaciones que proceden del derecho comparado, de la legislación en puntuales sectores del ordenamiento, o de la labor de los Tribunales, son aún insuficientes y sólo parcialmente útiles para la conformación de una sólida norma de lealtad en nuestra cultura constitucional. Sin embargo, no cabe negar que la eficacia de una Constitución se presenta como una exigencia ineludible, aunque no a cualquier precio. Cualidades para el orden constitucional como la nobleza, la rectitud, la honradez y la honestidad, pero también la solidez de un pacto constitucional afianzado sobre una sociedad capaz de generar vínculos sólidos de confianza, son imprescindibles para generar una comunidad segura de un mínimo respeto simultáneo hacia lo común pero también hacia lo particular. Porque la Constitución no es solo un orden jurídico sino expresión de una situación cultural en desarrollo, nos dice Häberle.

Por ello, el principio de lealtad exige, no una devoción ni un fanatismo absoluto por la Constitución ni tampoco una aceptación reacia y resignada de la misma, sino el trabajo por el compromiso de aquello y aquellas personas en las que una comunidad cree aun en la diversidad, adoptándose reglas de comportamiento en la configuración del derecho, en el ejercicio del poder, y en la gobernanza multinivel, que llegan al punto de convertir el conocimiento y la cultura socio-política en elementos inescindibles de la lealtad. Lo contrario, pues, a la lealtad es el engaño, el esencialismo, el dogmatismo, la falta de honestidad, la confrontación, el modelo de adversarios, la falta de empatía hacia el otro sujeto, la traición, e incluso la ignorancia — consentida o no, fomentada o no- La lealtad implica, pues, aceptar la norma según la cual no podamos alegar el incumplimiento de lo ajeno para justificar el incumplimiento de lo propio, porque en el fondo debe movernos el apego hacia el pacto constitucional, aun a pesar de que no siempre el resto lo vea del mismo modo. Y por tales motivos, la lealtad también impone una cierta actitud «valerosa»: la capacidad de una sociedad para enfrentarse a su pacto constitucional como un todo. Valga como ejemplo, la necesidad de abordar nuestro modelo territorial de Estado, auténtica cuenta pendiente. 
La conformación de un Derecho constitucional presidido por la norma de lealtad obliga a militar en la democracia constitucional, y obliga también a reflexionar sobre el modelo normativo que pretendemos configurar: un Derecho constitucional del enemigo, o un Derecho constitucional del infractor. Y supone, por tales motivos, observar la Constitución desde una dimensión proactiva y pedagógica, y no sólo desde su faceta reactiva o represora.

Resulta evidente, ante un déficit de lealtad constitucional constante y prolongado en el tiempo - en los operadores políticos, pero también en la doctrina-, que se necesita una revisión de la eficacia del pacto constitucional desde dicho principio. Y ante ello la reforma constitucional también emerge con fuerza. Pero conviene abrirnos a esta posibilidad con cautelas, con prudencia y con realismo. Si la lealtad exige compromiso constante, y las muestras de deslealtad han sido insuficientes o se encuentran en un momento histórico actual en el que política y derecho se encuentran desbordados por los acontecimientos, es dudoso que la apertura de un proceso de reforma constitucional tras largos déficits de manutención constitucional pueda cambiar estas dinámicas. Las panaceas ante momentos difíciles no existen, y sí todo lo más determinados cauces para retomar el camino de la plena normatividad constitucional. Quizá por ello un intento de «Pacto de Estado por la renovación constitucional» pueda servir para comenzar a aunar reformas políticas, legislativas y constitucionales. Una medida que pide debate, análisis y reflexión en la sede privilegiada del Parlamento, lo cual no es incompatible para al poco tiempo lanzar un proceso formalizado de reforma constitucional.

En el fondo, tras la idea de Constitución late la de construcción de una identidad colectiva que no olvide los individualismos y que no esencialice ciertos dogmas. La lealtad casa mal con el «cortoplacismo», y exige una combinación inteligente de una política y un derecho duro y blando a la vez: la firmeza de la fuerza del derecho, con la generación de una cultura jurídico-política sosegada, libre y razonada; de una educación en Constitución.

Será necesario al tiempo seguir descubriendo qué lugar ocupa la norma de lealtad como principio constitucional, superando planteamientos estatocéntricos, egocéntricos y rupturistas. Pero para ello quizá deberíamos tomar conciencia de los rasgos que caracterizan nuestra cultura jurídica para replantear la forma de hacer política y derecho. Porque como señalaba la profesora Ferraresse, el criterio de la mayoría ha sido siempre un débil elemento del sistema anglosajón, en una especie de mandato imperativo «redimensionado» pero perfectamente democrático; mientras en el sistema continental, el nuestro, el cuerpo político de la mayoría gubernamental viene representado por el mítico y omnipotente Leviathán hobbesiano.

Porque en efecto el Derecho constitucional es, simple y llanamente, equilibrio, se necesita un principio de lealtad que impida que «Todo cambie para que todo siga igual», recordando las míticas palabras de Lampedusa en El Gatopardo. 
Title:

Constitutional Loyalty and Democracy

\title{
Summary:
}

1. Premises. 2. Origin and evolution of the principle of constitutional loyalty. 3. Legal basis and rationale behind the principle of constitutional loyalty. 4. Constitutional loyalty and the legal order. 5. Constitutional loyalty and the exercise of power. 6. Constitutional loyalty in a multi-level system of governance. 7 . Conclusions.

\section{Resumen:}

El presente estudio se enmarca en la problemática de la vigencia y eficacia de la Constitución de 1978 a partir de la configuración dogmática del principio de lealtad. Se parte para ello de un dato relevante: la lealtad no encuentra un acomodo específico en el texto de nuestra Carta Magna, aunque ha sido elaborado doctrinal y jurisprudencialmente en otros sectores del ordenamiento, en otros niveles de gobierno y en el derecho comparado. Sin embargo, su vigencia es evidente e incluso necesaria a la luz de la evolución de nuestro sistema constitucional, sin que este ámbito de estudio haya recibido un análisis detenido por la doctrina. La lealtad se conecta, por ello con un triple postulado: el principio democrático, la supremacía constitucional en perspectiva multinivel, y la doble dimensión formal/material de la Constitución; pero sobre todo confronta y conjuga la necesaria compatibilidad del derecho con la política, y de la ley con la democracia. Desde estas premisas el presente trabajo analiza el origen y evolución del principio, y su fundamento y justificación, para con posterioridad abordar la proyección de la lealtad hacia el ordenamiento, hacia la configuración del poder, y hacia el constitucionalismo multinivel.

\begin{abstract}
:
The analysis carried out in this paper addresses the problematic issue of the validity and effectiveness of the 1978 Constitution, on the basis of a dogmatic approach to the loyalty principle. The paper starts with the relevant fact that loyalty cannot be expressly found in the constitutional text of the Spanish Magna Carta, albeit case-law and scholars have developed said concept in other areas of the legal order, for other levels of government and in Comparative Law. Nevertheless, its validity is not only apparent but necessary in light of the evolution of our constitutional system, and yet, this issue has not been thoroughly examined by the legal doctrine. Hence, loyalty is argued to be based on three tenets: the democratic principle, constitutional supremacy from a multi-level perspective, and the twofold formal/material dimension of the Constitution. Above all, the loyalty principle confronts and brings together the much needed compatibility between Law and Politics in addition to that between Law and
\end{abstract}


Democracy. On this basis, the present paper explores not only the origin and evolution of the loyalty principle, but also its basis and rationale, so as to address its role in the legal order and in the context of the configuration of power and of multi-level constitutionalism.

\section{Palabras clave:}

Principio de lealtad constitucional; Colaboración de poderes; Constitucionalismo multinivel; Pacto constitucional; Modelo territorial de Estado.

\section{Key words:}

Constitutional loyalty principle; Loyal cooperation between powers; Multi-level constitutionalism; Constitutional agreement; Territorial Organisation of the State. 